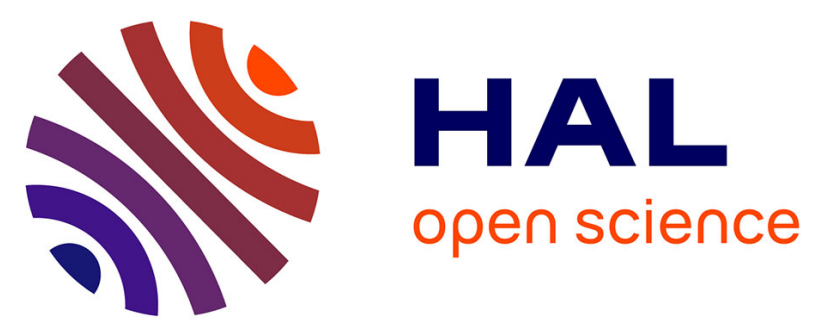

\title{
Development of TiO2 Nanomaterials and Dyes Selection (using DFT) for DSSC Applications -A Stepwise Review
}

\author{
P.M. Anbarasan, C.Indira Priyadharsini, R. Sathiyapriya, V. Hariharan, K.
} Parabakaran, V. Aroulmoji

\section{- To cite this version:}

P.M. Anbarasan, C.Indira Priyadharsini, R. Sathiyapriya, V. Hariharan, K. Parabakaran, et al.. Development of TiO2 Nanomaterials and Dyes Selection (using DFT) for DSSC Applications -A Stepwise Review. International journal of advanced Science and Engineering, 2019, 06 (02), pp.1326-1350. 10.29294/IJASE.6.2.2019.1326-1350 . hal-03093086

\section{HAL Id: hal-03093086 \\ https://hal.science/hal-03093086}

Submitted on 7 Jan 2021

HAL is a multi-disciplinary open access archive for the deposit and dissemination of scientific research documents, whether they are published or not. The documents may come from teaching and research institutions in France or abroad, or from public or private research centers.
L'archive ouverte pluridisciplinaire HAL, est destinée au dépôt et à la diffusion de documents scientifiques de niveau recherche, publiés ou non, émanant des établissements d'enseignement et de recherche français ou étrangers, des laboratoires publics ou privés. 


\title{
Development of $\mathrm{TiO}_{2}$ Nanomaterials and Dyes Selection (using DFT) for DSSC Applications -A Stepwise Review
}

\author{
P.M.Anbarasan*1, C.Indira Priyadharsini 1,2, R.Sathiyapriya ${ }^{3}$, V.Hariharan, \\ K.Parabakaran ${ }^{4}$, V.Aroulmoji ${ }^{3}$ \\ ${ }^{1}$ Department of Physics, Periyar University, Salem - 636 011, Tamil Nadu, India. \\ ${ }^{2}$ Muthayammal College of Arts \& Science, Rasipuram, Namakkal- 637408, Tamil Nadu, India. \\ ${ }^{3}$ Center for Research and Development, Mahendra Engineering College, \\ Mallasamiduam, Namakkal - 637 503, Tamil Nadu, India \\ ${ }^{4}$ PG \& Research Department of Physics, Mahendra Arts and Science College, \\ Kalipatti, Namakkal District, Tamilnadu 637 501, India
}

\begin{abstract}
Dye-sensitized solar cell (DSSC) or Graetzel cell is a less expensive solar cell belonging to the group of thin film solar cells. The advantages of DSSCs are mainly due to low cost production, low energy payback time, flexibility, performance at diffuse light and multicolor options. The present review gives a detailed summary and evaluation of the DSSCs. The role of $\mathrm{TiO}_{2}$ in the fabrication process as a photoanode to improve the high performance of DSSCs also discussed in detail. Structural modifications during the fabrication of the device are discussed along with the factors affecting to improve the efficiency of the DSSCs. Wide ranges of dyes were identified using Density Functional Theory (DFT) for HOMO-LUMO calculations. On the other hand, Doping plays a major role on the band structure and trap states of $\mathrm{TiO}_{2}$, which in turn affect the important properties such as conduction band energy, charge transport, recombination and collection. High-throughput methods may also be employed to achieve a rough prediction on the suitability of dopants for the specific synthesis methods. It was found that nearly every employed photoanode can be used to increase the device performance, indicating that the improvement in efficiency is not so much caused by the dopant itself. The current available knowledge on TiO2 as a Photoanodic material provides remarkable light harvesting efficiency in connection with perovskite solar cells and DSSCs.
\end{abstract}

KEYWORDS: Dye-sensitized solar cell (DSSC), Density Functional Theory (DFT), $\mathrm{TiO}_{2}$, Photoanodic material, perovskite solar cells

\section{INTRODUCTION}

Today, majority of solar cells manufactured in the world are based on silicon. There are several types of silicon solar cells, one of which is bulk silicon solar cells, which provide high conversion efficiency but require expensive materials. Then there are thin-film solar cells, which significantly reduce costs at the expense of decreased conversion efficiency. Nonsilicon compound semiconductor solar cells are expected to provide conversion efficiency at the same level as silicon crystal solar cells, but raise concerns about environmental load and the use of rare metals. The cost to generate power using single crystalline solar cells is about $40 \mathrm{yen} / \mathrm{kWh}$ and still there is demand for the development of novel lowcost high-efficient silicon free solar cells. One of nextgeneration solar cells is expected to satisfy these demands is dye-sensitized solar cells. Regan and Grätzel [1] reported high-efficient cells using nanoporous titanium oxide semiconductor electrodes in the presence of ruthenium $(\mathrm{Ru})$ metal complex dyes and iodine/iodine electrolyte solutions in the journal of Nature in 1991. Since then, many studies have been actively carried out on DSSCs and revealed their performance comparable to thin films of amorphous silicon [2]. These DSSCs have the advantages of low cost, lightweight and easy fabrication, but issues include in durability and further improvement in their spectral responses. To respond to these issues, many attempts have been made, such as solidifying electrolytes and identifying novel materials and their structures, but there have been no great breakthroughs yet. This review was initiated with the aim of developing practical DSSCs. This is a report on the consideration given to the various dopants with the $\mathrm{TiO}_{2}$ layer and to enhance the efficiency of DSSCs.

\subsection{Dye Sensitized solar Cells}

The first photovoltaic cell designed by O'Regan and Grätzel in 1991 [1] is working based on the principle of plant photosynthesis. These photovoltaic solar cells are later known as Dye Sensitized Solar Cell (DSSC) that is environment friendly and low cost with an efficiency reached of upto $15 \%$. In recent years, the DSSCs have attracted by researchers to its fundamental and technological significance as new generation of solar cells. In the development of thinfilm techniques, researchers are facing several setbacks in the efficiency of the cells that is half that of the more commonly used silicon-based cells. The schematic process describing the conversion of light 
into electrons in dye-sensitized solar cells is depicted in Figure 1.

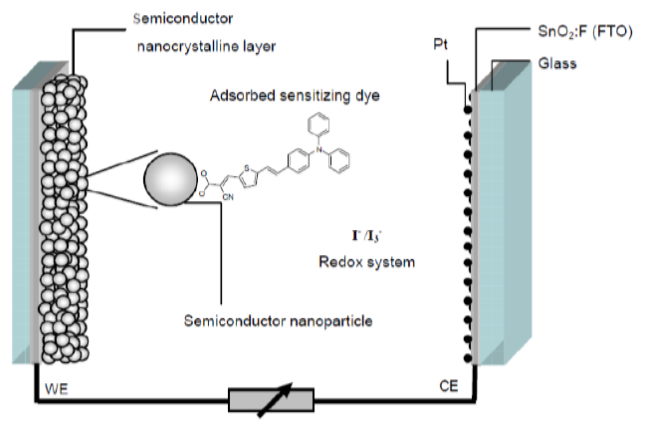

Figure 1 The conversion of light into electrons in conventional Dye-Sensitized Solar Cells

\subsection{Electrode Materials used for Solar Cells}

There are few important nanostructured electrode materials have been used for the development of solar cells, such as carbon electrodes (Single-walled carbon nanotube (SWCNT), multi-walled carbon nanotube (MWCNT), graphene oxide (GO) and fullerene, metal oxides $\mathrm{CTiO}_{2}$, fluorinated tin oxide, $\mathrm{SnO}_{2}$, boron doped $\mathrm{ZnO}$ and $\left.\mathrm{Cu}_{2} \mathrm{O}\right)$ and conducting polymers (Poly(3,4-ethylenedioxythiophene), poly(styrenesulfonate) (PSS), poly-3-hexylthiophene and polyaniline) electrodes etc. These types of electrode materials were greatly enhanced the power conversion efficiency $(\eta)$ of solar cells.

\subsubsection{Carbon Based Electrodes}

Among the carbon electrodes, carbon nanotubes (SWCNT and MWCNT) was discovered by Iijima [3] in 1991 are the most promising electrodes for the solar cell applications possess extraordinary mechanical, electrical, and optical properties. Also, it possesses unique mechanical and electronic properties. Moreover, graphene and MWCNT nanocomposite has been prepared and used as counter electrode in DSSCs [4]. Zhu et al [5] overviewed various carbon based electrode materials used in photovoltaic cells (PVC), such as organic solar cells, silicon based solar cells and DSSC.

A hard carbon spherule (HSC) was used as a counter electrode for DSSCs which can render 5.7\% of conversion efficiency [6]. A fullerene derived poly (3-hexylthiophene:phenyl-C61-butyric acid methyl ester (P3HT:PCBM) films were synthesized by ink-jet printing method and employed for high performance solar cell applications [7]. Susarova et al [8] reported a systematic analysis of seven different biscyclopropane adduct solvents to enhance the performance of the organic bulk-heterojunction solar cells. An excellent review on DSSCs based on counter electrodes was reported by $\mathrm{Wu}$ et al [9]. The authors discussed the importance of counter electrodes based on transparency and flexibility, metals and alloys, carbon materials, conductive polymers, transition metal compounds, and hybrids, respectively. The fabrication of a counter electrode for DSSCs using carbon material produced with the organic ligand 2methyl-8-hydroxyquinolinol (Mq) was reported by Kumar et al [10]. The carbon material showed power conversion efficiency (PCE) of $4.25 \%$ and fill factor (FF) of 0.51 which are slightly lower than those of the platinum (Pt) based counter electrode which showed a PCE of $5.86 \%$ and FF of 0.68 .

Gnanasekar et al [11] studied the Pt-free, low-cost and efficient counter electrode with carbon wrapped $\mathrm{VO}_{2}(\mathrm{M})$ nanofiber for dye-sensitized solar cells. The results revealed that the high power conversion efficiency of $6.53 \%$ under standard test condition of simulated 1SUN illumination at AM1.5 G, which was comparable to the $7.39 \%$ observed for conventional thermally decomposed Pt CE based DSSC under same test conditions.

\subsubsection{Metal Oxide Based Electrodes}

Metal oxide electrode materials emerged as another important class of functional groups covering solar cell applications [12]. Thin layer of titanium oxide [13], zinc oxide films [14] have been synthesized by using sol-gel method and used for solar cell applications. These electrodes absorbed UV light, but transparent in the visible region. Electrochemically deposited nanoporous ZnO on FTO electrode do not favor in the photoelectrode studies and limited PCE value of about $2.4 \%$ was obtained [15]. The studies proved that $\mathrm{TiO}_{2}$ based electrodes provided better performances than the $\mathrm{ZnO}$ based nanofibres. Kang et al [16] fabricated a near infra-red transparent film electrode by multi-cathode magnetron sputtering method with $\mathrm{GeO}_{2}$ and $\mathrm{In}_{2} \mathrm{O}_{3}$ as target. The resulting bulk-heterojunction of organic solar cell exhibited good cell performance with a fill factor (FF) of $67.38 \%$, JSC of $8.438 \mathrm{~mA} \mathrm{~cm}^{-}$ 2 and PCE of $3.44 \%$. Aluminium doped zinc oxide (AZO) nanoparticles were prepared in isopropyl alcoholic medium and used with different stabilizers (Polyvinylpyrrolidone, acetyl acetone and 3,6,9trioxydeconoic acid) which exhibited higher efficiency in inverted solar cell applications [17]. A cobalt-doped nickel oxide and activated carbon electrodes have been used for DSSC which as produced $4.9 \%$ of energy conversion efficiency [18].

An excellent review was recently published by Gao et al., [19] on transition metal compounds based counter electrode for DSSCs. The authors summarized the recent progress on the transition metal compound based counter electrode catalysts containing carbides, nitrides, oxides, sulfides, phosphide, selenides, borides, silicide, and telluride toward the regeneration of the traditional iodide redox couple. The benefits and drawbacks of each kind of CE catalyst are also discussed. The Nanoarchitectures in DSSCs: metal oxides, oxide perovskites and carbon-based materials were reviewed by Shaikh et al [20]. The charge separation, effective transportation, collection and recombination processes were also discussed. Different nanostructured materials, metal oxides, oxide perovskites and carbon-based 
composites have also been reported for photoanodes, and counter electrodes.

\subsubsection{Polymer Based Electrodes}

Photovoltaic Solar Cells (PSCs) have attracted significant attention owing to their potential advantages such as large surface area and low-cost $[21,22]$. PSCs are mainly used to improve the electrode sensitivity, selectivity, broad absorption properties, charge carrier mobility and high stability. A semi-transparent and surface free polymer (PEDOT:PSS) electrode has been fabricated by spray coating method and evaluated in organic solar cells studies, the evaluated semi-transparent electrodes power conversion efficiency $(\eta)$ of $2 \%$ [23]. Roesch et al [24] reported a non-inverted polymer (Poly[9(1-octylnonyl)-9H-carbazol-2,7-diyl]-2,5-

thiophenediyl-2,1,3-benzothiazol-4,7-diyl-2,5-

thiophenediyl (PCDTBT)):Phenyl C61 butyric acid methyl ester composite based solar cells sealed with $\mathrm{TiO}_{2} / \mathrm{Al}$ which leads to a notable improvement in the efficiency with durability of 18,000 hrs under ambient conditions.

A series of zwitterionic ammonium and neutral amino organic molecules are introduced into inverted PSCs as cathode interlayer and showed power conversion efficiency (PCE) as high as $8.07 \%$ was demonstrated by Zhang et al [25]. When compared to the devices without interlayer, all the devices exhibit significant improvements of the device parameters by reducing the work function of indium tin oxide (ITO) cathode. These results pave the way to the design of effective cathode interlayer materials. Lee et al [26] reported surface interpenetration between conducting polymer and PET substrate for mechanically reinforced ITO-free flexible organic solar cells, exhibited best performance of average power conversion efficiency. Ramachandran et al [27] studied polymer based counter electrodes for DSSC and prepared counter electrodes with PEDOT:PSS incorporated with MWCNTs and compared with the standard platinum counter electrode and examined their possibility for use as transparent counter electrodes for DSSC application.

Recently, an excellent review on the applications of polymers in solar cells was reported by Hou et al [28]. They reviewed the achievements on the applications of polymers in solar cells are discussed. The benefits of polymers in solar cells, the challenges for practical application, and possible solutions are also discussed.

\subsubsection{Nanocomposite Based Electrodes}

Nanocomposites are inevitable electrode materials in all kinds of electrochemical applications including sensors [29], biosensors [30,31], supercapacitors [32], batteries and solar cells etc. The combination of two or more dissimilar materials can be used to control the morphological behaviour and for the improvement of overall activities. Wang et al [33] reported MWCNT/polypyrrole composite as an efficient counter electrode for DSSC and obtained PCE of $6.2 \%$. Low-defect and water soluble graphene nanosheet/platinum nanoparticles composite have been prepared for DSSC which showed efficiency of $6.69 \%$ [34]. Inverted organic solar cells based on reduced graphene oxide (RGO)/Titanium oxide (TiOx) composite has been successfully prepared by sol-gel method [35], the resulting solar cells produces short circuit current of $9.85 \mathrm{~mA} \mathrm{~cm}-2$ and PCE of $3.82 \%$. Stubhan et al [36] reported highest performance value of fill factor and PCE value were markedly enhanced by using silver nanowire/metal oxide (AgNWs) composite ie FF of $62 \%$ and PCE of $2.7 \%$. Harnchana et al [37] reported the hierarchical $\mathrm{Fe}_{3} \mathrm{O}_{4}$-reduced graphene oxide nanocomposite grown on $\mathrm{NaCl}$ crystals for triiodide reduction in dye-sensitized solar cells. The combination exhibit an excellent catalytic activity toward the reduction of triiodide to iodide in DSSCs.

\subsection{The Role of $\mathrm{TiO}_{2}$ in DSSCs}

$\mathrm{TiO}_{2}$ is a popular material for solar energy applications due to large band gap, suitable band edge levels for charge injection and extraction, the long lifetime of excited electrons, exceptional resistance to photo corrosion, high surface area for higher dye loading, non-toxicity and low cost [3840]. This material is more stable compared to other metal oxides. This material occurs naturally in three crystalline forms; anatase (tetragonal), rutile (tetragonal) and brookite (orthorhombic). For DSSCs, anatase is the most commonly used phase due to its superior charge transport. The tetragonal anatase crystal structure is made up of a chain of distorted $\mathrm{TiO}_{6}$ octahedrons, which results in a unit cell containing four $\mathrm{Ti}$ atoms and eight $\mathrm{O}$ atoms [4143]. It has prepared by sol-gel processes with amorphous and annealing at elevated temperatures to achieve desired crystal structure. The crystallization temperature is limited by the anatase-rutile transition. Since rutile is thermodynamically most stable polymorph of $\mathrm{TiO}_{2}$ at all temperatures.

The anatase to rutile transition temperature depends sensitively on preparation conditions. Because of their different band structures, mixed phases of anatase and rutile generally cause the trapping of charge carriers and promote recombination processes. They are mostly undesirable in DSSC electrodes, although there are some studies suggesting a small amount of rutile nanoparticles can enhance device performance [4446]. Generally, DSSCs employ rutile $\mathrm{TiO}_{2}$ to suffer from lower CB compared to anatase, leading to a lower $\mathrm{V}_{\mathrm{oc}}$. In addition, reduced dye adsorption and charge transport lower the obtainable Jsc [47-49]. Because of these complications, rutile is not frequently used in DSSCs. Sopian et al [50] reviewed the performance of titanium dioxide for flexible DSSCs and compared with conventional silicon solar cells. The properties of flexible substrates very unique that provide advantages compared to the 
rigid substrate. The recent achievement on flexible dye sensitized solar cell with titanium dioxide as photoanode material were also discussed.

\subsection{Methods used in the Structural Modifications} of $\mathrm{TiO}_{2}$ in DSSCs

The $\mathrm{TiO}_{2}$ material can be synthesized in several ways; the most commonly used methods are:

\section{Sol-gel synthesis}

The sol-gel method is a versatile process that can be employed to make nanoparticles of ceramic materials. A colloidal suspension is made by hydrolyzing and polymerizing metal oxide precursors. The precursor typically is an inorganic metal salt or a metal organic compound. Frequently used precursors for $\mathrm{TiO}_{2}$ are titanium tetrachloride $\left(\mathrm{TiCl}_{4}\right)$ and titanium isopropoxide (TTIP). When the polymerization is complete and the solvent has evaporated, the sol forms a gel. Heat treatment will transform the gel into the desired $\mathrm{TiO}_{2}$ nanoparticle [51].

\section{Hydrothermal synthesis}

For the hydrothermal method a titanium precursor (TTIP) is mixed with water and a peptizer $\left(\mathrm{HNO}_{3}\right)$, after which the mixture is treated in an autoclave at elevated temperatures and pressures. After autoclaving the mixture is calcined to obtain $\mathrm{TiO}_{2}$ nanoparticles [52].

\section{Solvothermal synthesis}

The solvothermal method is similar to the hydrothermal method, with the exception that the used solvent is non-aqueous. By choosing high boiling point solvents it is possible to achieve much higher temperatures, increasing the control over the particle formation [53].

Flame spray pyrolysis

For flame spray pyrolysis (FSP), titanium precursor is dissolved in a solvent to generate a source solution. This solution is vaporized using a spray nozzle onto a substrate which is kept at elevated temperatures $\left(300-500^{\circ} \mathrm{C}\right)$. During spraying the solvent evaporates due to the elevated temperature and nanoparticles are formed [54].

\section{Anodization}

$\mathrm{TiO}_{2}$ nanotubes can be grown directly from titanium metal by applying a potential to a metal foil in a fluoride containing electrolyte solution. The tube length and diameter can be controlled through the anodization time and potential, electrolyte composition and $\mathrm{pH}$. The amorphous nanotubes are then annealed at elevated temperatures to achieve crystalline $\mathrm{TiO}_{2}$ nanotubes $[55,56]$.

\section{Micelle method}

With the help of surfactants, micelles of $\mathrm{TiO}_{2}$ precursor are formed in solution. Upon heat treatment these are converted to $\mathrm{TiO}_{2}$ nanoparticles [57].

\section{Direct oxidation}

Titanium can be treated with oxidizing agents to yield $\mathrm{TiO}_{2}$ nanostructures [58] similar to anodization.

\section{Sonochemical synthesis}

By applying ultrasound to a solution can cause intense local heating, high pressures and enormous heating and cooling rates. This can be used to synthesize $\mathrm{TiO}_{2}$ nanoparticles with high aspect ratios [59].

\section{Microwave synthesis}

Electromagnetic radiation can be used to heat up dielectrics to form nanostructures. A major advantage is the fast processing times due to the rapid heat transfer [60].

\section{Electrospinning}

An electrical charge is used to draw fibres from a solution, resulting in $\mathrm{TiO}_{2}$ nanostructures with high aspect ratios [61]. Compact $\mathrm{TiO}_{2}$ films for electron blocking layers are synthesized through the following methods.

\section{Spin coating}

The solution of $\mathrm{TiO}_{2}$ precursor is spin coated on a substrate to form a thin layer of compact $\mathrm{TiO}_{2}$ [62].

\section{Spray pyrolysis}

This method is similar to that described for the synthesis of $\mathrm{TiO}_{2}$ nanoparticles, with the exception that the particles form a dense layer on the substrate [63].

\section{Atomic layer deposition}

A substrate is alternating exposed to a $\mathrm{TiO}_{2}$ precursor and $\mathrm{H}_{2} \mathrm{O}$, resulting in the deposition of atomically thick layers. The thickness of the layer can accurately be controlled through the number of cycles [64].

\section{Thermal oxidation}

A thin layer of titanium is deposited by sputtering or evaporation and subsequently heated to high temperatures in the presence of oxygen to oxidize the film which forms a compact $\mathrm{TiO}_{2}$ layer [65].

\section{Electrochemical deposition}

A compact layer of $\mathrm{TiO}_{2}$ can be deposited from a $\mathrm{TiO}_{2}$ precursor solution by electrochemical deposition. The layer is subsequently crystallized by heating [66].

\section{Pulsed laser deposition}

For pulsed laser deposition a $\mathrm{TiO}_{2}$ precursor is pressed to form a disk which is used as a laser target. The laser vaporizes the target and the vapor condenses on the substrate forming a thin layer [67, 68].

\subsection{Methods to Introduce Dopant on $\mathrm{TiO}_{2}$-lattice}

The most common method is simply mixing a dopant precursor with the $\mathrm{TiO}_{2}$ precursor solution. This method can be employed in the sol-gel, hydrothermal, solvothermal, spray pyrolysis, atomic layer deposition, electrochemical deposition, sonochemical, microwave and electrospinning methods [69].

For pulsed laser deposition a dopant precursor is mixed with the titanium precursor and pressed to form a disk that can be used as a target for the laser. By immersing $\mathrm{TiO}_{2}$ structure into an electrolyte solution containing different dopant and applying voltage to electrochemically doped $\mathrm{TiO}_{2}[70]$. 
For anodization and thermal oxidation, a Tidopant alloy can be used. The dopants can be grouped into separate categories that share common electronic configurations. These are (earth) alkali metals, metalloids, non-metals, transition metals, post-transition metals and lanthanides. In some cases co-doping with two or more dopants is applied to further increase device performance. Each dopant can separately enhance device properties [71]. One dopant can reinforce the effect of the other dopant [72] or one dopant may counter act some of the detrimental effects caused by the other dopant [73]. Hoye at al [74] reviewed the importance of $\mathrm{ZnO}$ and $\mathrm{TiO}_{2}$ can be used as active layers, photoanodes, buffer layers, transparent conducting oxides, holeblocking layers, and intermediate layers. Doping is essential to tailor the materials properties for each application. The usefulness of dopants and their impact in solar cells are discussed. In addition, the advantages, disadvantages, and commercial potential of the various fabrication methods of these oxides are presented.

Duan et al [75] studied a series of Sn-doped $\mathrm{TiO}_{2}$ with Sn content ranging from 0.25 to $1 \mathrm{~mol} \%$ was successfully synthesized, and its performance as the photoanode was investigated. The optimum efficiency of $8.31 \%$ was found at $0.5 \mathrm{~mol} \%$ Sn-doped TiO2 based DSSCs, which gave an efficiency improved by $12.1 \%$ compared with that of the cells based on pure $\mathrm{TiO} 2$ (7.45\%). Doping of $\mathrm{TiO}_{2}$ for DSSCs was reviewed by Roose et al. [76]. Generally, doping has a major effect on the band structure and trap states of $\mathrm{TiO}_{2}$, which in turn affect important properties such as the conduction band energy, charge transport, recombination and collection. The authors reviewed the usefulness of high-throughput methods may be employed to achieve a rough prediction on the suitability of dopants for a specific synthesis method.

The electron and hole dynamics upon photon excitation in DSSCs, using real-time evolution of electronic states through time-dependent density functional theory was reported by Meng and Kaxiras [77]. The authors examined the influence of various factors on the dynamics of electrons and holes, including point defects (vacancies) on the $\mathrm{TiO} 2$ surface, variations in the dye molecular size and binding geometry, and thermal fluctuations which result in different alignments of the electronic energy levels. They concluded that the dissociated adsorption of the dye molecules leads to faster electron injection dynamics by reducing interfacial dipole moments; oxygen vacancy defects stabilize dye adsorption and facilitate charge injection, at the cost of lower open circuit voltage and higher electron-hole recombination rate.

Dopants often inhibit the growth rate of the $\mathrm{TiO}_{2}$ nanoparticles, resulting in smaller particles [78]. This is in many cases beneficial since assemblies made from smaller particles have a larger surface area per volume of mesoporous $\mathrm{TiO}_{2}$ compared to large particle assemblies. The increased surface area accommodates more dye, leading to higher light absorption and current densities. The main advantage of high light absorption is that thinner films can be used in photovoltaic devices, resulting in a reduction of recombination, which benefits both Jsc and $\mathrm{V}_{\mathrm{OC}}$.

Morphology is a further factor that influences the properties of $\mathrm{TiO}_{2}$. One-dimensional structures such as nanotubes have superior charge transport over nanoparticle assemblies, but have less surface area and thus adsorb less dye [79]. This implies that onedimensional structures will benefit more from dopants that increase dye adsorption, whereas nanoparticle assemblies will benefit more from doping that leads to increased charge transport. The dopant source can also influence the effectiveness of doping and it has been shown that organic sources lead to better performances than inorganic salts [80]. Furthermore, doping influences the anatase to rutile phase transition [81]. The above factors complicate the study of the effect of doping on the electronic properties of $\mathrm{TiO}_{2}$ as it is hard to distinguish and quantify whether an improvement is caused by increased absorption or electronic effects.

In short, doping can affect five different properties of anatase $\mathrm{TiO}_{2}$.

$>$ Flat-band potential. VFB can be shifted either positively or negatively; a positive shift is indicative of a downward shift of the $\mathrm{CB}$ and $\mathrm{EF}$ while a negative VFB shift indicates an upward shift of $\mathrm{CB}$ and $\mathrm{EF}$. A positive shift of VFB makes electron injection easier, increasing Jsc. Because of a smaller difference between EF of $\mathrm{TiO}_{2}$ and the HTM $\mathrm{V}_{\mathrm{OC}}$ is decreased. A negative shift of VFB will have the opposite effect on Jsc and Voc.

$>$ Recombination rate. A decrease in the number of defect states usually enhances the electron lifetime and reduce recombination rate, resulting in an increase in $V_{O C}$. Because of the dependence on trap states for electron transport based on the trap-detrap mechanism, this can however lead to a decrease in electron mobility and Jsc.

$>$ Electron transport rate. An increase in shallow trap states can lead to enhanced electron mobility and thus a higher Jsc. Simultaneously the introduced trap states can promote recombination which leads to a decreased $V_{\text {oc. }}$.

$>$ Dye adsorption. The dopant can change the growth rate of $\mathrm{TiO}_{2}$ particles resulting in differently sized particles, affecting the amount of adsorbed dye and number of grain boundaries. Additionally, the dopant may affect dye adsorption by a change in binding affinity of the dye to the doped surface.

$>$ Phase transition. Doping can inhibit the anatase-to-rutile phase transition, reducing rutile instigated charge recombination.

\subsection{Dye Materials}

Dye is responsible for light harvesting ability through photoelectron generation and electron transfer. Over the last two decades extensive 
research program were carried out to the development of new dyes. Several research works were reported for both organic (natural and synthetic) and inorganic (Ruthenium) dyes. Organic dyes have several advantages as sensitizers such as large absorption coefficients, wide variety of structures and relatively easy to modify. However, the performance of DSSCs based on organic dyes has not yet exceeded those based on Ru complexes. In $\mathrm{Ru}$ dyes, the electron transfer will takes place at a much faster rate than the back reaction.

Moreover, Small band gap energy materials are used as dye for DSSC. This is because the photons energy cannot be absorbed if it is smaller than the material's band gap energy. The sensitizer needs to be stable for over 108 times redox reactions for long lifetime cell. The most common used inorganic materials utilized in laboratory are three Ru based sensitizers: N3, N719 and black dyes. Ru based sensitizer has a faster electron injection speed than the electron recaptured by the oxidized sensitizer. N3 dye cis RuL2(SCN)2 (L=2,2-bipyridyl-

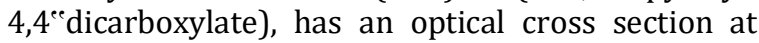
$530 \mathrm{~nm}$, giving the material the best Light Harvesting Efficiency (LHE) compared with other sensitizers at around $99.8 \%$. LHE is calculated using by the absorption length $(\alpha)$, of the sensitizer and the nanocrystalline film thickness, $d$, as shown in eq. 1.1. $\operatorname{LHE}(\lambda)=1-10^{-\alpha \mathrm{d}}$

The absorption length, $\alpha$, can be obtained using the sensitizer's concentration in the nanocrystalline film at full monolayer coverage, $\sigma \Omega$, and the optical absorption cross-section of the sensitizer, $C$.

$$
\alpha=\sigma \mathrm{C}
$$

However, N3 sensitizer could not absorb energies from near red spectrum. Therefore, new sensitizers such as K19 and K77 have been developed [82]. N719 exhibits similar characteristics to N3, but provides higher voltage for DSSC. The absorption of incident light in the DSSCs is realized by specifically engineered dye molecules placed on the semiconductor electrode surface.

To achieve a high light-to-energy conversion efficiency in the DSSC, the properties of the dye molecule as attached to the semiconductor particle surface are essential. Such desirable properties can be summarized as:

(i) Absorption: The dye should absorb light at wavelengths up to about 920 nanometers, i.e. the energy of the exited state of the molecule should be about $1.35 \mathrm{eV}$ above the electronic ground state corresponding to the ideal band gap of a single band gap solar cell [83].

(ii) Energetics: To minimize energy losses and to maximize the photovoltage, the exited state of the adsorbed dye molecule should be only slightly above the conduction band edge of the $\mathrm{TiO}_{2}$, but yet above enough to present an energetic driving force for the electron injection process. For the same reason, the ground state of the molecule should be only slightly below the redox potential of the electrolyte.

(iii) Kinetics: The process of electron injection from the exited state to the conduction band of the semiconductor should be fast enough to outrun competing unwanted relaxation and reaction pathways. The excitation of the molecule should be preferentially of the MLCT-type.

(iv) Stability: The adsorbed dye molecule should be stable enough in the working environment (at the semiconductor-electrolyte interface) to sustain about 20 years of operation at exposure to natural daylight, i.e. at least 108 redox turnovers [84].

(v) Interfacial properties: Good adsorption to the semiconductor surface.

(vi) Practical properties: For example the high solubility to the solvent is used in the dye impregnation. These can be considered as the prerequisites for a proper photovoltaic sensitizer. However, the factors that actually make the dye-sensitization work efficiently and yield good photovoltaic performance in the practical cell.

The reported efficiency for different $\mathrm{Ru}$ complex such as N3, N712, N719, Z910, K19, N945, K73, N621, Z907, Z955, HRS-1 and Blackdye is $10.0 \%$, $8.2 \%, 11.2 \%, 10.2 \%, 7.0 \%, 9.6 \%, 9.0 \%, 9.6 \%, 7.3 \%$, $8.0 \%, 9.5 \%$ and $10.8 \%$ respectively [85]. Recently, an excellent review on Ruthenium Complexes as Sensitizers in Dye-Sensitized Solar Cells was reported by Sadig Aghazada and Nazeeruddin [86]. This review might be helpful for the development of DSSC technology and to prove its market value.

\subsection{Electrolyte}

Electrolyte is the material that filled between the spaces of the nanoporous electrode. The purpose of electrolyte is to donate electrons to oxidized sensitizer to prevent the excited electrons recaptured by the sensitizer. It has to be a transparent material that allows the light to go through and, at the same time, has good conductivity and fast redox reaction. Moreover, it needs to have long term stability in many aspects including chemical, optical and especially the interfacial stability that relates to desorption and degradation of dye from oxide film. The most commonly used is liquid iodide/tri iodide redox couple dissolved in organic solvents. Organic solvent is the major material that gives the iodide/tri iodide ion dissolution and diffusion environment. The recent progress in the field of liquid, solid-state, and quasisolid-state electrolytes for DSSCs was reviewed by $\mathrm{Wu}$ et al [87]. It is believed that quasi-solid-state electrolytes, especially those utilizing thermosetting gels, are particularly applicable for fabricating high photoelectric performance and long-term stability of DSSCs in practical applications. The ideal 
characteristics of the redox couple for the DSSC electrolyte [88].

1. Redox potential thermodynamically (energetically) favorable with respect to the redox potential of the dye to maximize cell voltage.

2. High solubility to the solvent to ensure high concentration of charge carriers in the electrolyte.

3. High diffusion coefficients in the used solvent to enable efficient mass transport.

4. Absence of significant spectral characteristics in the visible region to prevent absorption of incident light in the electrolyte.

5. High stability of both the reduced and oxidized forms of the couple to enable long operating life.

6. Highly reversible couple to facilitate fast electron transfer kinetics.

7. Chemically inert toward all other components in the DSSC.

\subsection{Counter Electrode}

Counter electrode in DSSC needs to provide high conductivity as it needs to provide the liquid electrolyte electrons to complete the redox reaction in very short time for lifetime stability and preventing the electron recapture. Currently, the most common used material is Pt. This is because Pt has high electron mobility that can regenerate the electrolyte rapidly. Moreover, literatures show that, for example, using gold as the counter electrode and found that the electrolyte corrodes gold [89]. Pt, on the other hand, has high stability against electrolytes corrosives characteristic.

\subsubsection{Transparent Conductive Oxide (TCO)}

TCO is a wide bandgap n type semiconductor that consists of high concentration of free electrons. The most common ones are Tin 50 doped Indium Oxide (ITO), Fluorine doped Tin Oxide (FTO) and Aluminium doped Zinc Oxide (AZO or Al:ZnO) due to the good electrical conductivity, high transparency and the low material costs. The research in TCO began popular about one century ago when Badeger published a report in 1907 proposed the method of cadmium sputtering with thermal oxidation to produce $\mathrm{CdO}$ thin film [90]. Since then, numerous reports on transparent film deposition emerged. Undoped $\mathrm{SnO}_{2}, \mathrm{In}_{2} \mathrm{O}_{3}$ and $\mathrm{ZnO}$ were materials that are researched widely at the start. Doping with other materials showing much better characteristics was discovered later. Moreover, electronic devices utilizing this technique such as resistors, light trapping anti-reflection coatings, and thin film solar cells have been developed. Sixty years later, Holland reviewed the efforts that have been done in this field in his publication, describing the methods of fabrication, characteristics and applications. The research in TCO has not yet reaches its acme as abundant research projects are set to investigate a better TCO material with higher electron mobility [91]. Apart from the material itself, methods of depositing TCO were also examined closely. The common processes for fabricating TCO are evaporation [92-94], sputtering [95], reactive ion etching [96], chemical vapor deposition (CVD) $[97,98]$, spray pyrolysis [99], solution dipping, and chemical solution growth.

\subsubsection{Indium doped Tin Oxide (ITO)}

ITO is one of the most used TCO materials in industries and laboratories for the past decades due to its high transmittance (around 80\% to 90\%) and high conductivity [100]. However, when the material is placed at temperature over $300{ }^{\circ} \mathrm{C}$, its conductivity drops dramatically. This is due to the decrease in oxygen vacancies in high temperature, resulting in the decrease of electric carriers. Moreover, the scarcity of the expensive Indium material resulting in high material costs [101]. In addition to that, the toxicity of the material and the ease of reacting with hydrogen plasma, cause the researchers to look for a better substitution.

\subsubsection{Fluorine doped Tin Oxide (FTO)}

FTO is another type of TCO that have been widely used, especially in solar cells. This is due to its good stability at high temperature and its competitive cost in comparison with ITO. $\mathrm{SnO}_{2}$ itself is a semiconductor with very low conductivity and wide band gap (around $4 \mathrm{eV}$ ). An extrinsic dopant, such as $\mathrm{Sb}$ or $\mathrm{F}$, is added into the material. Fluorine doped $\mathrm{SnO} 2$ is more commonly used than the material doped with $\mathrm{Sb}$. This is due to the variation in resistivity with the amount of $\mathrm{Sb}$ doped. Another advantage of FTO is that it has high transmittance (> $80 \%$ or $85 \%$ depending on the thickness), especially in visible wave region [102]. Its resistivity can be as low as $2 \times 10^{-4} \mathrm{~cm}$, depending on the thickness of the film [103].

1.8.4 Aluminium doped Zinc Oxide (AZO or Al:ZnO)

An alternative material that has been widely discussed for ITO substitution is Al doped $\mathrm{ZnO}$. ZnO is a wide band gap $\mathrm{n}$ type semiconductor with wurtzite structure, categorized in II-VI group. It has high exciton binding energy, approximately $60 \mathrm{meV}$, which is higher than the $25 \mathrm{meV}$ of GaN. Therefore, $\mathrm{ZnO}$ has been a promising material in optoelectronic fields. However, undoped $\mathrm{ZnO}$ suffers from low conductivity (around $1-100 \mathrm{~cm}$ ), not compatible for use as electrodes. Therefore, like FTO, an extrinsic doping is normally added into the material to increase the carrier concentration, resulting in conductivity increase, at the same time, maintain the transmittance [104]. Both Zinc and Aluminium are inexpensive and abundant material. This gives AZO an advantage when comparing with ITO as it is relatively cheap [105]. Transparent conducting oxide (TCO)-coated glass was used as the substrate for the $\mathrm{TiO}_{2}$ photoelectrode. For high efficient solar cells, the substrate must have low sheet resistance and high transparency. In addition, sheet resistance should be nearly independent of the temperature because sintering of the $\mathrm{TiO}_{2}$ electrode is carried out at 450 to $500{ }^{\circ} \mathrm{C}$. Indium-tin oxide (ITO) is one of the most famous TCO materials. In spite of having low 
resistance at room temperature, ITO resistance increases significantly at high temperature in air. Usually, fluorine-doped $\mathrm{SnO} 2$ is used as the TCO substrate for DSSCs.

\subsection{Major Factors Affects in DSSC 1.9.1 Effect of Solvents}

A systematic study of DSSCs can be used at different solvent medium; this is associated with the structural and electronic distribution changes. Low volatile solvents are friendly atmospheric nature and they give different physical and chemical properties to the dye adsorbed on the counter electrode surface [106]. In one interesting report, a simple organic dye of CD-7 was dissolved in different solvents like DMF and THF to sensitize $\mathrm{TiO}_{2}$ photoelectrode [107], from CD-7 dye sensitized $\mathrm{TiO}_{2}$ film on THF bath exhibited larger adsorption energy value than that of DMF bath. Zhang et al [108] studied a systematic analysis of the effects of different polar solvent on the photovoltaic performance of thieno [3,4-b] thiophene/benzodithiophene (PTB7):(6,6)-phenylC71 butyric acid methyl ester (PC71BM). Methanol medium exhibited higher $\Delta$ value and low viscosity which could present a remarkable enhancement in the power conversion efficiency value from $6.55 \%$ to $8.13 \%$. Chen et al [107] reported the photophysical, photovoltaic and electrochemical impedance properties of the DSSCs based on THF or DMF bath were investigated. They showed that the DSSCs based on THF bath obtained the $\eta$ value $1.53 \%$, which is about twice as much as that of DMF bath.

\subsubsection{Effect of Temperature}

In DSSCs, temperature is one of the essential parameter which affects the contact angle values; as the contact angle value decreases, the temperature increases [109]. Large area compatible p-type nanocrystalline silicon has been synthesized by DC sputter coat method which has the possibility of enhancing the DSSC performance at room temperature [110]. Sing and Ravindra [111] theoretically over viewed the temperature dependence of solar cell studies in the range from $273-523 \mathrm{~K}$. The value of $V_{\mathrm{OC}}$ is decreases, while the value of $J_{\mathrm{sc}}$ increases upon increasing temperature [112].

\subsubsection{Effect of Atmosphere}

Guechi et al [113] studied and reported the effects of variation of water vapour performance by using two different solar cells such as nano crystalline silicon (nc-Si:H) and cadmium telluride (CdTe) which are exhibited efficiency value of $2.38 \%$ and $3.15 \%$ respectively. These results clearly indicated that the efficiency value for both the cells increases with increasing of water vapour. The solar power plants are often affected by the influence of acid rain atmosphere of $\mathrm{SO}_{2}$ on the durability [114]. After exposure of the acid rain atmosphere, the deterioration and reflectance drop was smaller in the thick glass mirror than thin glasses. In one report,
$\mathrm{Nb}-\mathrm{TiO}_{2}$ electrode doped with conducting organic polymer of MEH-PPV showed higher hybrid solar cells (HSC) performance than bare $\mathrm{TiO}_{2}$ based HSC [115]. Moreover, TiO2/MEH-PPV composite has been prepared under atmospheric conditions. Nan et al [116] used CdS nanorod arrays (NRs)/poly[2methoxy-5-(2'-ethylhexyloxy)-1,4-phenylene vinylene] (MEH-PPV) composite for HSC which is stable under ambient atmospheric conditions. Gimpel et al [117] studied the silicon wafer atmospheric study of aluminium back surface field (Al-BSF) solar cells by using an infra-red active secondary laser sulphur n-doped emitters an attractive path for the enhancement of PCE. In addition, polymer solar cells made of PTB7: PCBM has been investigated at two different environmental conditions (Inert and atmosphere) and the results revealing that atmosphere plays a crucial in the overall efficiency [118].

\section{FABRICATION TECHNIQUES \\ 2.1 Coating method}

A polymer solar cell based on ITO/PEDOT:PSS:P3HT:PCBM:Bpheng/Ag composite has been fabricated using spray coating technique at various annealing temperatures [119]. Xiong et al [120] used two different (Doctor Blading and spin coating) techniques for the fabrication of a novel polymer blended SCs. The authors found that homogeneous and uniform film was obtained from doctor blading method compared with spin coating of PSCs applications. As a result, Doctor Blading method exhibited higher PCE (4.46\%) compared with spin coated method. $\mathrm{TiO}_{2}$ nanoparticles film has been fabricated on stainless steel mesh by three different techniques (Sol-gel, dip coating and sputter coating method) and their DSSC performance have been studied [121].

Muhammed et al [122] studied the preparation of copper indium di-selenide (CIS) thin film by electro spray deposition technique (ESD) under roomtemperature atmospheric condition for the solar cell applications. Polypyrrole/functionalized MWCNT films on rigid FTO and flexible ITO coated polyethylene napthalate substrates have been prepared which are exhibited good PCE performance of $7.02 \%$ and $4.04 \%$ under room-temperature respectively [123]. A comparative study of $\mathrm{TiO}_{2}$ paste preparation methods using solvothermally synthesized anatase nanoparticles in DSSC was reviewed by Kadhim Al-Attaf et al [124]. They prepared TiO2 films using pastes of solvothermally synthesized anatase nanoparticles for the fabrication of solar cells. They also reported the detailed sideby-side comparison of different paste-forming techniques, with one yielding scattering films, and the other yielding non-scattering films.

\subsection{Printing Methods}

A flexible transparent copper nano wire mesh has been fabricated by simple transfer printing from flexible poly (dimethyl siloxane) as potential 
replacement for ITO electrodes in OSCs [125]. These electrodes have great potential to replace ITO for the making of low cost and large area flexible of OSCs. Kopola et al [126] used polymer (poly-3-hexyl thiophene (P3HT) and [6,6]-phenyl-C61-butyric acid methyl ester (PCBM) blend) based solar cells fabricated by high-throughput roll-to-roll (R2R) gravure printing method. The important parameters such as printing speed, ink properties and printability of the photoactive as well as the hole transport layer studies are optimized. In gravure printing method studies, the important printing parameters like ink viscosity, surface roughness, surfactance, surface energy and surface modification by plasma cleaning have been optimized to achieve homogeneous printing of multi layer organic photovoltaic (OPV) devices [127]. The authors tested highly boiling solvents (chlorobenzene, ortho-1,2dichlorobenzene, 1,2,4-trichlorobenzene and 1,2,3,4tetrahydro naphthalene) for P3HT:PCBM which showed Arrhenius behaviour up to 8 wt \%. Airbrush spray-coating is one of the fabrication methods developed for the preparation of polymer heterojunction solar cell device which reported the power conversion efficiency of $4.1 \%$ with good reproducibility [128]. Kopola et al [129] used a new kind of aerosol jet printing method for the fabrication of ITO free organic solar cells with an inverted layer sequence. The controlled printing parameters have been optimized such as chuck temperature, printing speed and number of printing passes.

\section{ELECTRON TRANSFER DYNAMICS}

DSSCs are photo electrochemical devices where several electron transfer processes are in parallel and in competition. The presence of a local electrostatic field is not required to achieve good collection efficiencies as it is the case for conventional p-n junction cells. Figure 2 summarizes the electron transfer processes occurring at the dyesensitized heterojunction Recent studies of the electron injection dynamics from the electronically excited state of [perylene dye] and [Ru(II)polypyridyl complexes] into the conduction band of the $\mathrm{TiO}_{2}$ demonstrated that the electron injection rate constant $\left(\mathrm{k}_{\mathrm{inj}}\right)$ are relatively similar $\mathrm{k}_{\mathrm{inj}}$ was reported to be $5 \times 10^{13} s^{-1}$ for perylene derivatives and $\mathrm{k}_{\mathrm{inj}}>4 \times 10^{14} \mathrm{~s}^{-1}$ for Ru-complexes $[130,131]$. Assuming, that the injection kinetics do not significantly change upon replacement of the electrolyte mediator by the solid-state charge transport material, the injection of electrons by the sensitizer in both the electrolyte cell and solid-state solar cell is expected to show similar characteristics [132]. Upon illumination, the sensitizer is photoexcited in a few femto seconds (eq. 1.3) and electron injection is ultrafast from excited dye $S^{*}$ to $\mathrm{TiO}_{2} \mathrm{CB}$ (eq. 1.4) on the subpicosecond time scale (intramolecular relaxation of dye excited states might complicate the injection process and change the timescale), where they are rapidly (less than 10 fs) thermalized by lattice collisions and phonon emissions.

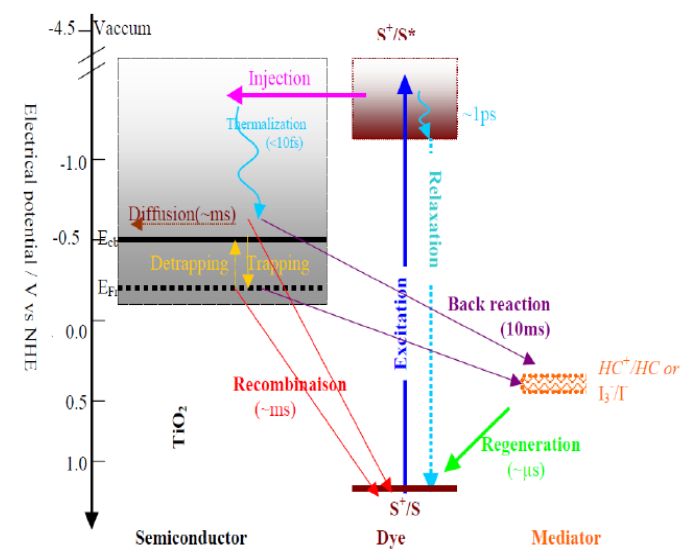

Figure 2 Schematic Diagram of Electron-Transfer Processes at the Dye-Sensitized Solar Cell

The relaxation of the excited dye $S^{*}$ occurring in the range of nanosecond (eq. 1.5) is rather slow compared to injection, ensuring the injection efficiency to be unity. The ground state of the sensitizer is then regenerated by $\mathrm{I}_{2}$ the microsecond domain (eq. 1.6), effectively annihilating $S+$ and intercepting the recombination of electrons in $\mathrm{TiO}_{2}$ with $\mathrm{S}^{+}$(eq. 1.7) that happens in the millisecond time range. This is followed by the two most important processes - electron percolation across the nanocrystalline film and the redox capture of the electron by the oxidized relay (back reaction, eq. 1.8), within milliseconds or even seconds.

Photoexcitation:

$\mathrm{S} / \mathrm{TiO}_{2}+\mathrm{hv} \longrightarrow \mathrm{TiO}_{2}$

Charge injection:

$\mathrm{S}^{*} / \mathrm{TiO}_{2} \longrightarrow \mathrm{S}^{+} / \mathrm{TiO}_{2}+$ e- $\mathrm{CB}\left(\mathrm{TiO}_{2}\right)$

Relaxation:

$\mathrm{S}^{*} / \mathrm{TiO}_{2} \longrightarrow \mathrm{S} / \mathrm{TiO}_{2}+\mathrm{ho}^{\prime}+\Delta$

Regeneration:

$\mathrm{S}^{*} / \mathrm{TiO}_{2}+2 \mathrm{I}^{-} \longrightarrow \mathrm{S} / \mathrm{TiO}_{2}+\mathrm{I}_{2}$

Regeneration (in solid-sate DSSC):

$\mathrm{S} / \mathrm{TiO}_{2}+\mathrm{MeOTAD} \longrightarrow \mathrm{S} \mathrm{TiO}_{2}+\mathrm{MeOTAD}^{+}$

Recombination:

$\mathrm{S}^{+} / \mathrm{TiO}_{2}+\mathrm{e}-\left(\mathrm{TiO}_{2}\right) \longrightarrow \mathrm{S} / \mathrm{TiO}_{2}$

Back reaction:

e- $\left(\mathrm{TiO}_{2}\right)+\mathrm{I}_{2} \quad \longrightarrow \quad \mathrm{I}_{2}$

\section{PHOTOVOLTAIC CELL PERFORMANCE}

A photovoltaic cell is a device, which converts incident light to electrical energy. Generation of electrical power under illumination is achieved by the capability of the photovoltaic device to produce voltage over an external load and current through the load at the same time. This is characterized by

Anbarasan et al., 
the current-voltage (I-V) curve of the cell at certain illumination and temperature (See Figure 3). When the cell is short circuited under illumination, the maximum current, the short circuit current $\left(\mathrm{I}_{\mathrm{oc}}\right)$, is generated, while under open circuit conditions no current can flow and the voltage is at its maximum, called the open circuit voltage $\left(\mathrm{V}_{\text {oc }}\right)$. The point in the IV-curve yielding maximum product of current and voltage, i.e. power, is called the Maximum Power Point (MPP). Another important characteristic of the solar cell performance is the fill factor $(f f)$.

\section{(a) Open Circuit Photovoltage (Voc)}

The Voc is the difference in potential between the two terminals in the cell under light illumination when the circuit is open.

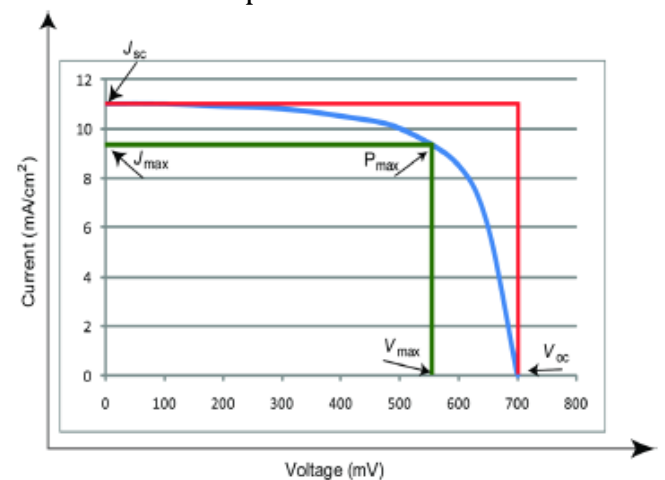

Figure 3 Illustrations of Current-Voltage Characteristics of a Solar Cell.

It is dependent on both the Fermi level of the semiconductor and the level of dark current. The theoretical maximum of the cell is determined by the difference between the Fermi level of the semiconductor and the redox potential of the holeconductor. It is measured when the current through the cell is equal to zero (open circuit).

(b) Short Circuit Photocurrent (Jsc)

$J s c$ is the photocurrent per unit area $\left(\mathrm{mA} / \mathrm{cm}^{2}\right)$ when an illuminated cell is short circuited. It is dependent on several factors such as the light intensity, light absorption, injection efficiency and regeneration of the oxidized dye. It is strongly related to the IPCE and theoretical values on the Jsc can be calculated from the IPCE spectrum. Figure 3 shows an illustration of current-voltage.

(c) Fill Factor (FF)

The fill factor measures the ideality of the device and is defined as the ratio of the maximum power output per unit area to the product of $\mathrm{V}_{\mathrm{OC}}$ and Jsc Several factors can influence the $f f$, such as a high inner resistance (e.g. a bad counter electrode), which will give a low fill factor and a decreased overall efficiency.

$$
F F=\frac{V_{\max } X J_{\max }}{V_{O C} X J_{S C}}
$$

\section{(d) Solar Energy to Electricity Conversion} Efficiency ( $\eta)$

The overall solar energy to electricity conversion efficiency of a solar cell is defined as the ratio of the maximum output of the cell divided by the power of the incident light. It can be determined by the photocurrent density measured at short circuit (Jsc), the open circuit photovoltage $\left(\mathrm{V}_{\mathrm{OC}}\right)$, the fill factor of the cell (ff), and the intensity of the incident light ( $\left.P_{\text {in }}\right)$ as shown in eq. 2.0.

$$
\eta=\frac{V_{o c} \times J_{S C} \times F F}{P_{\text {in }}} \times 100 \%
$$

Since it is dependent on all the three first factors under standard conditions it is of great importance to optimize each one of them for high overall efficiency.

\section{CHARACTERISTICS OF DSSC}

The photovoltaic (PV) mechanism of DSSC is different from that of conventional p-n-type solar cells. The DSSC has other unique characteristics such as the following:

(i) High energy conversion efficiency: DSSC efficiency equal to that of the amorphous-Si solar cell has been obtained during laboratory development and efficiencies greater than $10 \%$ may be possible.

(ii) Low-cost fabrication: The DSSC is very simple to construct and is made of low-cost materials. Fabrication costs will therefore be less than that for conventional solar cells.

(iii) Abundant supply of component materials: Oxide semiconductors such as $\mathrm{TiO}_{2}$, dye, and iodine are abundantly available. Although metal deposits of $\mathrm{Ru}$ are limited, the amount of Ru complex used in the DSSC is only $1 \times 10^{-7}$ mol cm${ }^{-2}$.

(iv) Good potential for colorful, adaptable consumer products: Colorful and transparent solar cells can be made using various kinds of dyes, depending on the use of the cell. For example, transparent solar cells could be used in place of windowpanes. Additionally, the use of a plastic substrate, rather than glass, is possible if low temperature processing of the $\mathrm{TiO}_{2}$ film preparation $\left(<250^{\circ} \mathrm{C}\right)$ is available and would expand the use of DSSC.

(v) Low potential for environmental pollution: The $\mathrm{TiO}_{2}$, dyes, and iodine used in the DSSC are nontoxic. The only component that could potentially cause harm is the organic solvents used in the electrolyte solution. Future research should be directed toward developing a solid-state electrolyte.

(vi) Good recyclability: The organic dye photosensitizers adsorbed on the electrode can be removed by washing the electrode with alkali solutions or combustion, providing recyclability of the DSSC. 
6. Difference between the Conventional Silicon \& Dye Sensitized Solar Cells

(i) Upon illumination, light absorption and charge carrier transport are separated in dye sensitized solar cell, whereas both processes are established in the semiconductor conventional silicon solar cell.

(ii) In the DSSCs, the nanoparticles of oxide semiconductor are simply too small to sustain a build-in electric field and thereby the charge transport occurs via diffusion. In a conventional $p$ - $n$ junction the presence of an electric field is necessary for an efficient charge separation.

(iii) DSSCs are majority charges carrier devices in which the electron transport occurs in the $\mathrm{TiO}_{2}$ and the hole by the mediator. Thereby, the recombination processes can be only confined at the interface. Inside a $p$ - $n$ junction minority and majority charge carriers coexist in the same bulk volume. Hence these cells are very sensitive to the presence of the trace impurities or defects, which can act as recombination centers.

\section{EFFICIENCY}

A novel titanium oxide paste based on Pechini solgel method and nanocrystalline titanium oxide powders have been successfully developed by Opara Krasovec et al [133]. The dye-sensitized layers have been used to assemble dye-sensitized solar cells with acetonitrile- and ionic liquid-based electrolyte. Overall conversion efficiencies were determined under standard test conditions are $10.2 \%$ for acetonitrile and $7.3 \%$ for ionic liquid-based electrolyte. Enhanced performance of a nanocrystalline dye-sensitized solar cell based on polyurethane dendrimers was reported Veerapandian et al [134]. The performance of the devices fabricated with dendrimers were appreciably good compared to that fabricated without dendrimers and in one case the photocurrent, photovoltage, fill factor and energy conversion efficiency achieved were $10.6 \mathrm{~mA} \mathrm{~cm}^{-2}, 900$ $(\mathrm{mV}), 0.51$ and $8.5 \%$, respectively, under simulated sunlight with AM 1.5 at $50 \mathrm{~mW} \mathrm{~cm}^{-2}$.

Ahmed Al-Ghamdi et al [135] Improved solar efficiency by introducing graphene oxide in purple cabbage dye sensitized $\mathrm{TiO} 2$ based solar cell. The solar efficiency was compared with natural and commercial dye (N719) under similar experimental conditions and observed that the natural (purple cabbage) dye has higher efficiency $(0.150 \pm 0.020 \%)$ than $\mathrm{N} 719(0.078 \pm 0.002 \%)$. It was further evaluated that the efficiency of the fabricated solar cell could improve by incorporating graphene oxide. The efficiency of the TiO2 dye-sensitized solar cell was found to increase from $0.150 \pm 0.020 \%$ to $0.361 \pm 0.009 \%$ by incorporating graphene oxide into purple cabbage dye.

Prabu et al [136] investigated the efficiency of photo electrode using $\mathrm{ZnO}$ doped $\mathrm{TiO}_{2}$ nanoparticles was prepared by sol-gel method with opuntia prickly pear dye. Photocurrent-voltaic characterization of nanocrystaline natural dye solar cell using I-V studies. It was found that the levels of short-circuit current (Jsc), open-circuit voltage (Voc), fill factor (FF) and overall conversion efficiency ( $\eta$ ) was found to be 0.5392 . Similarly, Sanad et al [137] reported the plasmonic enhancement of low cost mesoporous $\mathrm{Fe}_{2} \mathrm{O}_{3}-\mathrm{TiO}_{2}$ loaded with palladium, platinum or silver for dye sensitized solar cells. The mesoporous $\mathrm{Fe}_{2} \mathrm{O}_{3}$ $\mathrm{TiO}_{2}$ nanoparticles $(6.5-8.0 \mathrm{~nm})$ have been synthesized via simple hydrothermal route. The authors concluded that silver doped sample showed the highest photovoltaic performance.

Lim et al [138] studied the promotional effect of silver nanoparticles on the performance of $\mathrm{N}$-doped $\mathrm{TiO}_{2}$ photoanode-based dye-sensitized solar cells. The authors concluded that the DSSC performance was due to the reduced band gap energy and retarded charge recombination that resulted from the introduction of plasmonic Ag nanoparticles on the surface of $\mathrm{N}-\mathrm{TiO}_{2}$. The optimum Ag content for $\mathrm{N}-\mathrm{TiO}_{2}$ was found to be 10 $\mathrm{wt} \%$. The enhanced solar energy conversion efficiency demonstrated by the $\mathrm{N}-\mathrm{TiO}_{2}-\mathrm{Ag}$ nanocomposite makes it a promising alternative to conventional photoanodebased DSSCs. Wang et al [139] studied just by adding $2 \%$ of $\mathrm{ZnO}$ into $\mathrm{TiO}_{2}$ based photoanodes, the dye adsorption is increased, the light scattering is enhanced, and electron transfer is improved, all accomplished without compromising large surface areas afforded by $\mathrm{TiO}_{2}$ nanoparticles. As a result, conversion efficiency of $9.53 \%$ is realized, which is $12 \%$ higher than $\mathrm{TiO}_{2}$ photoanodes without $\mathrm{ZnO}$ addition.

Kumar and coworkers [136] studied the effect on interfacial charge transfer resistance by hybrid cosensitization in DSSC applications. $\mathrm{TiO}_{2}$ nanoparticles are used for the fabrication of DSSC based on the hybrid co-sensitization of natural dye and organic dyes. The interfacial charge transfer resistance phenomena of the DSSC were determined by electrochemical impedance spectroscopy. Photovoltaic efficiency of $0.1377 \%$ is achieved for the fabricated DSSC with co-sensitization of natural and organic dyes.

Prabu et al [140] investigated the $\mathrm{ZnO}^{-\mathrm{TiO}_{2}}$ and methanol treatment of Red Indian Spinach fruit dye dipped photo-anode in the DSSC showed the conversion efficiency $(\eta)$ of 0.825 . Similarly in the samples $\mathrm{ZnO}$ doped $\mathrm{TiO}_{2}$ with turmeric as a natural dye showed the excellent solar energy conversion efficiency of $0.87 \%$. Table 1 Shows the Summary of some efficiency of DSSCs with $\mathrm{TiO}_{2}$ as a photoanode. Bakhshayesh et al [141] reported the enhanced performance of dye-sensitized solar cells aided by $\mathrm{Sr}, \mathrm{Cr}$ co-doped $\mathrm{TiO}_{2}$ xerogel films made of uniform spheres. The solar cells were fabricated based on different concentrations of $\mathrm{Sr}$ and $\mathrm{Cr}$. Jsc was dramatically improved in the cell based on the codoped xerogel film. The cell contains 0.075 at. \% $\mathrm{Sr}$ and 2.5 at. $\% \mathrm{Cr}$ showed the efficiency of $7.89 \%$.

The prominence of using Betalain and Cubebin extracted from Ocimum tenuiflorum and Piper 
nigrumas as natural dye sensitizers for the design of eco-friendly DSSC's was reported by Ranjitha et al [142]. The conversion efficiencies for the Cubebin and Betalain and mixed dye based solar cells are estimated as $0.392 \%$ and $0.38 \%$ respectively. The highest conversion efficiency for natural photo sensitizers based solar cell is attributed due to the absorption of wider range of solar spectrum.

The usefulness of Pd-Co-doped carbon nanofibers with photoactivity as effective counter electrodes for DSSCs was reported by Nasser and Barakat et al [167]. The introduced nanofibers revealed good performance as the fabricated DSSC attains relatively high short-circuit current density $\left(U_{s c}\right)$ of $9.8 \mathrm{~mA} / \mathrm{cm}^{2}$ and open circuit voltage $\left(V_{\mathrm{OC}}\right)$ of $0.705 \mathrm{~V}$. They also showed the importance of nanofibers in chemical stability because the metallic nanoparticles are sheathed inside a crystalline carbon shell.

Qian Hou et al [162] reported the synthesis of visible-light-response iodine-doped $\quad \mathrm{TiO}_{2}$ nanocrystals and their implementation as photoanodes of DSSCs. Interestingly, the I-TNCsbased cell are higher conversion efficiency of $10.0 \%$ under $30 \mathrm{~mW} \mathrm{~cm}^{-2}$ illuminations. The improved performance of expanded visible-light harvesting, lowered recombination resistance together with prolonged electron lifetime $\tau_{\mathrm{e}}$. These results suggest substantial potential of $\mathrm{TiO}_{2}$ nanocrystals with controlled doping in DSSC application.

Jung et al [163] reported $\mathrm{TiO}_{2}$ nanofibers had an anatase crystallite structure and possessed thicknesses of $80-150 \mathrm{~nm}$, a maximum specific surface area of $103.3 \mathrm{~m}^{2} / \mathrm{g}$, maximum porosity of $80.5 \%$ and maximum efficiency of $4.6 \%$, which was significantly higher than that of typical $\mathrm{TiO}_{2}$ nanofibers. Similarly, Nitrogen (n)-doped titanium dioxide $\left(\mathrm{TiO}_{2}\right)$ was prepared by Kang et al [164] with varying doping using sol-gel process. The n-doped$\mathrm{TiO}_{2}$ electrode showed the maximum conversion efficiency with an open-circuit voltage (Voc) of 0.726 $\mathrm{V}$, a photocurrent (Jsc) of $10.52 \mathrm{mAcm}^{-2}$, a fill factor of $63.6 \%$, and an efficiency of $4.86 \%$, compared to $0.751 \mathrm{~V}, 7.4 \mathrm{mAcm}^{-2}, 67.1 \%$, and $3.73 \%$, respectively, for the undoped (u-doped) $\mathrm{TiO}_{2}$ electrode. $\mathrm{Nb}$-doped anatase $\mathrm{TiO}_{2}$ nanoparticles were prepared by the sol-gel process followed by a hydrothermal treatment and successfully used as the photoanodes by Sang Gyun Kim [165] in organic dye-sensitized solar cells. The Nb-doped $\mathrm{TiO}_{2}$ exhibited a positive shift of the conduction band edge (CB) compared to the undoped $\mathrm{TiO}_{2}$.

Table 1. Summary of some efficiency of DSSCs with $\mathrm{TiO}_{2}$ as a photoanode

\begin{tabular}{|c|c|c|c|c|c|c|}
\hline Sample & $\begin{array}{l}\text { Open-circuit } \\
\text { voltage } \\
\text { Voc, } \mathrm{V}(\mathrm{mV})\end{array}$ & $\begin{array}{l}\text { Short-circuit } \\
\text { current density } \\
\text { Jsc }(\mathrm{mA} / \mathrm{cm} 2)\end{array}$ & $\begin{array}{l}\text { Fill } \\
\text { factor } \\
\text { (ff) }\end{array}$ & $\begin{array}{l}\text { Efficiency } \\
\eta(\%)\end{array}$ & Year & Ref. \\
\hline $\mathrm{Cr}-\mathrm{TiO}_{2} / \mathrm{TiO}_{2} / \mathrm{FTO}$ & 780 & 15.2 & 0.71 & 8.4 & 2008 & {$[143]$} \\
\hline Ga- $\mathrm{TiO}_{2}$ & 710 & 12.44 & 0.51 & 4.57 & 2010 & [144] \\
\hline Iodine doped $\mathrm{TiO}_{2}$ & 715 & 14.1 & 0.67 & 7.0 & 2011 & [145] \\
\hline Eu3+-doped $\mathrm{TiO}_{2}$ & 770 & 9.61 & 0.69 & 5.16 & \multirow{2}{*}{2011} & \multirow{2}{*}{ [146] } \\
\hline Sm3+-doped $\mathrm{TiO}_{2}$ & 810 & 10.9 & 0.67 & 5.81 & & \\
\hline $\begin{array}{l}\mathrm{Au}-\mathrm{TiO}_{2} \text { core-shell } \\
\text { nanowires- }\end{array}$ & 690 & 14.2 & 0.67 & 6.7 & 2012 & {$[147]$} \\
\hline $\begin{array}{c}\text { PC DSSC (4 mm nc- } \\
\left.\mathrm{TiO}^{2} / 14 \mathrm{~mm} \mathrm{PC}-\mathrm{TiO}_{2}\right)\end{array}$ & 827 & 16.1 & 0.65 & 8.58 & 2013 & [148] \\
\hline Mg-doped $\mathrm{TiO}_{2}$ & 1210 & 1.80 & 0.55 & 1.2 & 2013 & {$[149]$} \\
\hline $\mathrm{Nb}$-doped $\mathrm{TiO}_{2}$ & 690 & 16.45 & 0.65 & 7.41 & 2013 & [150] \\
\hline $\mathrm{Cr}-\mathrm{TiO}_{2}$ & 714 & 9.82 & 0.72 & 5.02 & 2013 & [151] \\
\hline $\mathrm{N} / \mathrm{TiO}_{2}$ & 820 & 11.10 & 0.73 & 6.64 & 2014 & [152] \\
\hline Al-doped anatase $\mathrm{TiO}_{2}$ & 740 & 8.60 & 0.79 & 5.0 & 2014 & [153] \\
\hline TiO2/N719 (sol gel) & 730 & 11.95 & 0.68 & 5.93 & 2010 & {$[154]$} \\
\hline $\begin{array}{c}\text { TiO2/N719 } \\
\text { (solvothermal) }\end{array}$ & 760 & 17.23 & 0.65 & 8.51 & 2010 & [154] \\
\hline Sn doped $\mathrm{TiO}_{2}$ & 760 & 12.76 & 0.58 & 6.24 & 2015 & [155] \\
\hline TiO2/N3 dye/KI/I2/Pt & 760 & 2.5 & 0.40 & 1.5 & \multirow{3}{*}{2015} & \multirow{3}{*}{ [156] } \\
\hline $\begin{array}{c}\mathrm{TiO} 2 / \mathrm{N} 3 \text { dye } / \mathrm{KI} / \mathrm{I} 2 / p \text { - } \\
\text { chlorophenyl } \\
\text { terminated } \mathrm{G} 4 \\
\text { dendrimer } / \mathrm{Pt}\end{array}$ & 900 & 10.6 & 0.51 & 9.7 & & \\
\hline $\begin{array}{c}\mathrm{TiO} 2 / \mathrm{N} 3 \\
\text { dye/KI/I2/styrenyl- } \\
\text { TEMPO } \\
\text { terminated G4 } \\
\text { dendrimer/Pt }\end{array}$ & 890 & 8.6 & 0.53 & 8.1 & & \\
\hline $\begin{array}{c}\mathrm{La} / \mathrm{TiO}_{2} \\
\mathrm{~N} / \mathrm{TiO}_{2}\end{array}$ & $\begin{array}{l}730 \\
736\end{array}$ & $\begin{array}{c}8.88 \\
9.3\end{array}$ & $\begin{array}{l}0.71 \\
0.69\end{array}$ & $\begin{array}{l}4.58 \\
4.72\end{array}$ & 2016 & [157] \\
\hline
\end{tabular}

Anbarasan et al., 


\begin{tabular}{|c|c|c|c|c|c|c|}
\hline NLa/TiO2 & 728 & 10.5 & 0.73 & 5.33 & & \\
\hline Ca-doped TiO2 & 450 & 19.2 & 0.67 & 8.35 & 2013 & {$[158]$} \\
\hline $\mathrm{TiO}_{2}$ nanoflower & 693 & & 0.67 & 3.64 & 2019 & {$[159]$} \\
\hline $\begin{array}{c}\mathrm{TiO}_{2} / \mathrm{CH} 3 \mathrm{NH} \text { PbI3 } \\
\text { (Perovskite) }\end{array}$ & 973 & 8.9 & 0.75 & 13.0 & 2013 & {$[160]$} \\
\hline
\end{tabular}

$\mathrm{Zn}+\mathrm{Mg}$ co-doped $\mathrm{TiO}_{2}$ and the pure $\mathrm{TiO}_{2}$ nanoparticles were prepared by Liu et al [166] through the hydrothermal method. Under a simulated solar light irradiation of $100 \mathrm{~mW} \mathrm{~cm}^{-2}$, the cell based on doped $\mathrm{TiO}_{2}$ electrode achieved a conversion efficiency of $9.07 \%$, which is noticeably increased by $26.7 \%$ compared with undoped $\mathrm{TiO}_{2}$ based DSSC (7.16\%). The enhancement of conversion efficiency of the $\mathrm{Zn}+\mathrm{Mg}$ co-doped $\mathrm{TiO}_{2}$ was attributed to the positive shift of the flat band potentials and fast electron transport in $\mathrm{TiO}_{2}$ films.

Lee et al [167] prepared the two types of $\mathrm{TiO}_{2}$ coatings by sol-gel and solvothermal methods, the energy conversion efficiency of the solvothermal modified $\mathrm{TiO}_{2}$ was considerably higher than that on the sol-gel modified $\mathrm{TiO}_{2}$; approximately $8.51 \%$ (solvothermal) and 5.93\% (sol-gel) with the N719 dye under $100 \mathrm{~mW} / \mathrm{cm}^{2}$ of simulated sunlight respectively.

Feitao Li et al [168] prepared Erbium-doped $\mathrm{TiO}_{2}$ electrodes for the fabrication of solar energy cells. They showed the performance of the cells has been improved remarkably due to $\mathrm{Er}^{3+}$ doping. Photoelectrical conversion efficiency was enhanced from $4.83 \%$ to $6.05 \%$ by $\mathrm{Er}^{3+}$ doping under $\mathrm{AM}=1.5$ illumination, in which the effective area of the DSSC is $0.7 \times 0.7 \mathrm{~cm}^{2}$.

Lim et al [169] reported the boosting photovoltaic performance of DSSC Using silver nanoparticledecorated N,S-Co-Doped- $\mathrm{TiO}_{2}$ Photoanode. The DSSCs assembled with the $\mathrm{N}, \mathrm{S}-\mathrm{TiO}_{2} @$ Ag-modified photoanode demonstrated an enhanced solar-toelectrical energy conversion efficiency of $8.22 \%$, which was better than that of a DSSC photoanode composed of unmodified $\mathrm{TiO}_{2}(2.57 \%)$ under full sunlight illumination $\left(100 \mathrm{mWcm}^{-2}\right.$, AM $\left.1.5 \mathrm{G}\right)$.

Similarly, Ca salts $\left[\mathrm{CaSO}_{4}\right]$-doped $\mathrm{TiO}_{2}$ electrodes were prepared by Liu et al [170] with well-optimized condition by the hydrothermal method show an increase in short-circuit (Jsc), resulting in a power conversion efficiency (PCE) of 8.35\%, which is higher than that of the undoped $\mathrm{TiO}_{2}$ thin film $(7.33 \%)$. The doping of Ca shifts the flat band potential of $\mathrm{TiO}_{2}$ photoanode positively and increases the electron density indicated by the Mott-Schottky plot.

Moradzaman et al [171] studied the light scattering, harvesting and adsorption effects in dyesensitized solar cells are studied by through preparation of coated CNTs with $\mathrm{TiO}_{2}$ and $\mathrm{Zr}$-doped $\mathrm{TiO}_{2}$ nanoparticles in the forms of mono-and doublelayer cells. It is found that electron injection of monolayer $\mathrm{TiO}_{2}$ electrode is improved by introduction of $0.025 \mathrm{~mol} \% \mathrm{Zr}$, resulted in enhancement of its power conversion efficiency
(PCE) upto 6.81\% compared with $6.17 \%$ for pure $\mathrm{TiO}_{2}$ electrode.

Motlak et al [172] showed the incorporation of nitrogen atoms into the lattice of $\mathrm{TiO}_{2}$ nanofibers which led to enhancement of the absorption in the visible light region, the charge transfer, electron lifetime and the recombination reaction at the $\mathrm{TiO}_{2}$ photoelectrode/electrolyte interface as com-pared to the pristine $\mathrm{TiO}_{2}$ nanofibers. It was found that the overall conversion efficiency of DSSCs based on photoanode of $\mathrm{N}$-doped $\mathrm{TiO}_{2}$ nanofiber is significantly higher than DSSCs based on un-doped $\mathrm{TiO}_{2}$ nanofibers.

The effect of $\mathrm{Zr}$ doping on the performance of dyesensitized solar cells based on $\mathrm{Zr} / \mathrm{N}$-doped $\mathrm{TiO}_{2}$ photoelectrodes was reported by Jun-Yong Park et al [173]. DSSCs fabricated with a $0.01 \mathrm{M} \mathrm{Zr} / \mathrm{N}$-doped $\mathrm{TiO}_{2}$ photoelectrode achieved a maximum power conversion efficiency of $12.62 \%$ with a short-circuit current (Jsc) of $26.37 \mathrm{~mA} \mathrm{~cm}^{-2}$, open-circuit voltage (Voc) of $738 \mathrm{mV}$, and fill factor (FF) of $67.3 \%$ after $\mathrm{TiCl}_{4}$ treatment.

The $\mathrm{TiO}_{2}$ nanoparticles are surfacemodified via atom transfer radical polymerization (ATRP) with a hydrophilic poly (oxyethylene)methacrylate (POEM), which can coordinate to the $\mathrm{Ag}$ precursor, i.e. silver trifluoromethanesulfonate $\left(\mathrm{AgCF}_{3} \mathrm{SO}_{3}\right)$ was reported by Park et al [174]. The enhancement of $\eta$ is mostly due to the increase of current density, attributed to the improved electron transfer properties including electron injection, collection, and plasmonic effects without the negative effects of charge recombination or problems with corrosion.

Bendoni et al [175] investigated the effect of water in terpineol-based $\mathrm{TiO}_{2}$ screen-printing inks, commonly used for the deposition of photoanodes for dye-sensitized solar cells. The authors showed that water plays a major role to increase the dispersion and time stability of the particle suspensions, leading to an optimized flow behavior of the inks. They prepared modified inks with different amounts of water and analyzed by different techniques DLS, UV and so on. The results show strong impact of water on the dispersion of $\mathrm{TiO}_{2}$ inks and films. A $12 \%$ increase in efficiency was obtained compared to the un-modified system.

A low cost mesoporous $\mathrm{Fe}_{2} \mathrm{O}_{3}-\mathrm{TiO}_{2}$ nanoparticles has been synthesized by Sanad et al [176] from Abu Ghalaga ilmenite ore using simple hydrothermal route. Silver, platinum and palladium metals nanoparticles from spent catalysts have been extracted and deposited between the anatase $\mathrm{TiO}_{2}$ particles using in-situ reduction step. The as prepared materials were applied as photoanodes in 
DSSCs. The $\mathrm{Ag} @ \mathrm{Fe}_{2} \mathrm{O}_{3}-\mathrm{TiO}_{2}$ sample exhibited the maximum overall conversion efficiency $(\eta \%=4.5 \%)$ and it can be considered as a cost-effective photoanode for DSSCs.

Titanium nanotubes doped with boron used as the photoelectrode for dye-sensitized solar cells were investigated by Subramanian et al [177]. The material showed an enhanced performance with a photocurrent density of $7.85 \pm 0.20 \mathrm{~mA} / \mathrm{cm}^{2}$ and overall conversion efficiency $(\eta)$ of $3.44 \pm 0.10 \%$. The results of EIS measurement indicated that the longer electron lifetime and reduced $\mathrm{TiO} 2 /$ dye/electrolyte interface resistance for boron doped $\mathrm{TiO}_{2}$ nanotubes than that of undoped $\mathrm{TiO}_{2}$ nanotubes.

Wang et al [178] synthesized $\mathrm{Y}, \mathrm{N}$ co-doped $\mathrm{TiO}_{2}$ nanoparticles via a simple sol-gel method. The incorporation of yttrium and nitrogen increased the BET surface area and porosity of the nanoparticles, as the sample 100-300-0.5 reached $105.9 \mathrm{~m}^{2} / \mathrm{g}$, which largely improved the dye adsorption ability and obviously enhanced the Jsc. By optimizing doping amount of $\mathrm{TiO}_{2}$, sample 100-300-0.5, for which the doping concentration characterized by XPS survey was $0.30 \%$ and $0.48 \%$ of yttrium and nitrogen, respectively, showed the best efficiency of $5.41 \%$ without any post-treatments on the electrode, $18 \%$ higher than the un-doped sample100-0-0. According to EIS measurements, charge transfer resistance could decrease to as low as $39.3 \mathrm{U}$ in the co-doped samples, which was almost half of the undoped $\mathrm{TiO}_{2}$.

The photovoltaic performance of the quasi-solidstate dye-sensitized solar cells (DSSC) based on the Ta-doped $\mathrm{TiO}_{2}$ hierarchical spheres were investigated by Xiang et al [179]. The results show that the Ta-doped hierarchical TiO2 spheres photoelectrode shows a maximum conversion efficiency of $7.10 \%$, which is $29 \%$ higher than that of the undoped $\mathrm{TiO} 2$ spheres $(5.42 \%)$ due to the increase of both short-circuit current density and the open-circuit voltage.

Yang et al [180] reported the influence of dopant $F$ on band energetic and photo electrochemical properties of nanostructured $\mathrm{TiO}_{2}$ electrodes. The results showed that the content of $F$ plays an important role in the photoelectrochemical properties. The highest conversion efficiency of 8.07\% was obtained with $\mathrm{F}$-doped $\mathrm{TiO}_{2}$ electrodes containing F 0.05 (molar ratio) under irradiation of $100 \mathrm{~mW} \mathrm{~cm}^{-2}$ white light, about $11.3 \%$ higher than that of pure $\mathrm{TiO}_{2}$ electrodes. Facilitated by $\mathrm{TiO}_{2}$ particles adsorbing lanthanide ions in hydrosol, Ladoped $\mathrm{TiO}_{2}$ was produced by a hydrothermal method.

Geetha et al. [181] also prepared the pure and Aldoped anatase $\mathrm{TiO} 2$ nanoparticles by an acid tailored sol-gel method and successfully used as a photoanode for dye-sensitized solar cells. After $\mathrm{Al}$ doping, the conductivity of the $\mathrm{TiO}_{2}$ increases and it has a positive shift. The energy conversion efficiency of a cell based on 0.05 mol\% Al-doped $\mathrm{TiO}_{2}$ is significantly better, by about $4.6 \%$, compared to that of a cell based on undoped $\mathrm{TiO}_{2}$. The synthesized Aldoped $\mathrm{TiO} 2$ material is proven in detail to be a better photoanode material than pure $\mathrm{TiO}_{2}$. The synthesized $\mathrm{Al}$-doped $\mathrm{TiO}_{2}$ material is proven in detail to be a better photoanode material than pure $\mathrm{TiO}_{2}$ nanoparticles with a simple and versatile way to prepare excellent photoanode materials.

In 2015, Kakiage [182] reported highly-efficient dyesensitized solar cells with collaborative sensitization by silyl-anchor and carboxy-anchor dyes. The cells exhibited a high conversion efficiency of over $14 \%$ under one sun illumination.

Burschka et al [160] reported the sequential deposition as a route to high-performance perovskite-sensitized solar cells. Using this technique, the fabrication of solid-state mesoscopic solar cells greatly increased the reproducibility and their performances are allowed to achieve a power conversion efficiency of approximately 15 per cent. They also studied the long term stability of the cell using LED. Press release of EPFL shows that DSSC cell efficiency has been raised to a record $15 \%$.

Mozhgan Hosseinnezhad [183] studied the enhanced performance of DSSCs using Perovskite/DSSCs Tandem Design. N719 were applied in fabricating dye-sensitized solar cells as photosensitizers. The author achieved an $8.77 \%$ and $10.54 \%$ efficiency tandem solar cell formed by a top perovskite and DSSC based on organic dye and N719 for the bottom cell, respectively.

\section{Dye Selection using Density Functional Theory (DFT)}

Electronic absorption spectra and sensitized mechanisms were usually carried out by density functional theory (DFT) using Gaussian 03 package. The calculation is performed in order to understand the electronic transition of dye molecules in vacuum and suitable solvent. Experimental measurements of electronic absorptions are usually performed in solution. Solvent, especially polar solvent, could affect the geometry and electronic structure as well as the properties of molecules through the longrange interaction between solute molecule and solvent molecule. For these reasons, it is more difficult to make the Time Dependent DFT (TD-DFT) calculation quantitatively consistent. Though the discrepancy exists, the TD-DFT calculations are capable of describing the spectral features of any molecule because of the agreement of line shape and relative strength as compared with the vacuum and solvent.

The HOMO-LUMO gap of any dye molecule at B3LYP/6-311G(d,p) theory level is smaller than that in vacuum. This fact indicates that the solvent effects stabilize the frontier orbitals and induce the smaller intensities and red-shift of the absorption as compared with that in vacuum.

In order to obtain the microscopic information about the electronic transitions, the corresponding frontier molecular orbitals (MO) energies are checked. The absorption in visible and near-UV

\section{Anbarasan et al.,}


region is the most important region for photo-tocurrent conversion, so only the 20 lowest singlet/ singlet transitions of the absorption band in visible and near-UV region. The data is based on the 6$311 \mathrm{G}(\mathrm{d}, \mathrm{p})$ results with solvent effects involved. Commonly, the atom occupied by more densities of Highest Occupied Molecular Orbital (HOMO) should have stronger ability for detaching electrons, whereas the atom with more occupation of Lowest Unoccupied Molecular Orbital (LUMO) should be easier to gain electrons. This indicates that the transitions are photo induced charge transfer processes, thus the excitations generate charge separated states, which should favour the electron injection from the excited dye to semiconductor surface.

The following dye molecules were investigated for understanding the electronic transitions are: Tetrahydroquinoline [184], Indolocarbazole-3,4ethylenedioxythiophene, benzothiadiazole, IndolocarbazoleIndolocarbazole-quinoxaline and Indolocarbazolebenzoxadiazole [185], Stilbene Based Organic Dye [186], Indolocarbazole Dye [187], 4-Methyl-3Nitropyridine-1-Carbonitrile [188], 6-Amino-2Methylpyridine-3-Carbonitrile [189], 2aminopyrimidine-5-carbonitrile [190], 1,5Diaminoanthraquinone [191], Triphenylamine [192], 2-Amino-6-Nitrobenzothiazole[193], Anthracene Based Organic Dye [194], Metal Free Dye Sensitizers namely 2-hydroxynaphthalene-1,4-dione,3-(5-((1E)2-(1,4-dihydro-1,4-dioxonaphthalen-3-yloxy) vinyl) thiophen-2-yl)-2-isocyanoacrylic acid , anthocyanin dye [195], 4-Amino Stilbene [196], 2,3'- Diamino4,4'- Stilbenedicarboxylic [197], 4Phenoxyphthalonitrile Dye [198], 4Methylphthalonitrile [199], 4-Aminophthalonitrile [200], Phthalonitrile Derivatives [201], 4(Phenylthio) Phthalonitrile [202], 3,4Pyridinedicarbonitrile Phenoxyphthalonitrile [204], [203], 3Trifluoromethylcoumarin [205], 1,2-dihydroxy-9,10anthraquinone [206]. This indicates that the choice of the appropriate conjugate bridge in dye sensitizer is very important to improve the performance of DSSCs.

\section{CONCLUSION}

The present review clearly proposing the role of $\mathrm{TiO}_{2}$ as a photoanodic material in the fabrication of DSSCs and investigating various dyes using DFT since DSSCs are environmental friendly, capable of being highly efficient cell mainly due to the choice of suitable materials which enhance the generation of charge carriers and transportation will be within the cell structure.

In focus, the nanodimensional DSSCs are provided economically credible alternative to present day $p-n$ junction photovoltaics. By bearing in mind the importance of DSSCs the present review presents the requirements of practical sensitizers having high broad band with the absorption of visible and near infrared region of the electromagnetic spectrum. The existence of thermal and photochemical stability of the dyes is mainly due to the choice of proposed materials with suitable electrolytes definitely chelating to the semiconductor oxide surface and inject electrons into the conduction band with a quantum yield of unity, and owning suitable groundand excited state redox properties.

On the other hand, Investigations on solvent free electrolytes such as polymer based, and ionic liquid are considered as promising medium in order to generate and promote reducing process. In general, focus on commercializing dye sensitized solar cell with low power, flexible has been intensively investigated with the help of present review. It is found that the conversion efficiency of solar to electric power in full AM is around 1.5 sun light validated by accredited PV calibration laboratories has reached over $15 \%$ has been exhibited in recent years. This review clearly unleashes the role of $\mathrm{TiO}_{2}$ as a photoanode when compared to that of Si based solar cells in terms of low cost and ease of production, variation of performances as a function temperature, possessing bifacial configuration advantage for diffuse light, have transparency for power windows, color can be varied by selection of the dyes, invisible PV-cells based on near-IR sensitizers are feasible, apart from that they are outperforms of amorphous Si. Moreover, DSSC shows higher conversion efficiency than polycrystalline $\mathrm{Si}$ during the diffuse of light even in cloudy conditions. By bearing in mind the reviews of $\mathrm{TiO}_{2}$, Dyes using DFT it is concluded that nanocrystalline photovoltaic devices are becoming viable contender for large scale future solar energy converters.

\section{ACKNOWLEDGEMENT}

The authors V.A and R. S wish to thank DST-FIST$137 / 2013$, Government of India for providing financial support to carry out this work.

\section{REFERENCES}

[1]. Regan,B.O., Grätzel,M., 1991. A low-cost, high-efficiency solar cell based on dyesensitized colloidal $\mathrm{TiO}_{2}$ films, Nature, 353, 737.

[2]. Chiba,Y., Islam,A., Watanabe,Y., Komiya,R., Koide,N., Han,L., 2006. Dye-Sensitized Solar Cells with Conversion Efficiency of 11.1\%, J. J. Appl. Phys. 45, L638.

[3]. Iijima,S., 1991. Helical microtubules of graphitic carbon, Nature, 354, 56.

[4]. Choi,H., Kim,H., Hwang,S., Choi,W., Jeon,M., 2011. Graphene counter electrodes for dyesensitized solar cells prepared by electrophoretic deposition, Sol. Energy Mater. Sol. Cells 95, 323.

[5]. Zhu,H., Wei,J., Wang,K., Wu,D., 2009. Applications of carbon materials in photovoltaic solar cells, Sol. Energy Mater. Sol. Cells, 93, 1461. 
[6]. Huang,Z., Liu,X., Li,K., Luo,Y., Li,H., Song,W., Chen,L.Q., Meng,Q., 2000. Optimization the solid-state electrolytes for dye-sensitized solar cells, Electrochem. Commun., 9, 596.

[7]. Lim,G.H., Zhuo,J.M., Wong,L.Y., Wong,S.J., Chua,S.J., Chua,L.L., Ho,P.K.H., 2014. A transition solvent strategy to print polymer:fullerene films using halogen-free solvents for solar cell applications, Organic electronics 15 (2), 449 -460.

[8]. Susarova,D.K., Goryachev,A.E., Novikov,D.V., Dremova,N.N., $\quad$ Peregudova,S.M., Razumov,V.F., Troshin,P.A. 2014. Material solubility effects in bulk heterojunction solar cells based on the bis-cyclopropane fullerene adducts and P3HT, Sol. Energy Mater. Sol. Cells, 120, 30-36.

[9]. Jihuai $\mathrm{Wu}$, Zhang Lan, Jianming Lin, Miaoliang Huang, Yunfang Huang, Leqing Fan Genggeng Luo, Yu Lin,Yimin Xie and Yuelin Wei, Counter electrodes in dyesensitized solar cells, Chem.Soc.Rev., 2017, 46, 5975.

[10]. Rahul Kumar, Veena Sahajwalla and Parag Bhargava, Fabrication of a counter electrode for dye-sensitized solar cells (DSSCs) using a carbon material produced with the organic ligand 2-methyl-8hydroxyquinolinol (Mq), Nanoscale Adv., 2019, 1, 3192.

[11]. Subashini Gnanasekar, Pratap Kollu, Soon Kwan Jeong, Andrews Nirmala Grace, Ptfree, low-cost and efficient counter electrode with carbon wrapped $\mathrm{Vo}_{2}(\mathrm{M})$ nanofiber for dye sensitized solar cells, (2019) 9:5177, 1-12.

[12]. Sui, R., Charpentier,P., 2012. Synthesis of Metal Oxide Nanostructures by Direct SolGel Chemistry in Supercritical Fluids, Chem. Rev., 112, 3057-3082.

[13]. Kuwabaru, T., Sugiyama, H., Yamaguchi, T., Takahashi, K., 2009. Inverted type bulkheterojunction organic solar cell using electrodeposited titanium oxide thin films as electron collector electrode, Thin solid films, 517, 3766-3769.

[14]. White,M.S., Olson,D.C., Shaleen,S.E. Kopidakis,N., Ginley,D.S., 2006. Inverted bulk-heterojunction organic photovoltaic device using a solution-derived $\mathrm{ZnO}$ underlayer, Appl. Phys. Lett., 89, 143517.

[15]. Dunkel,C., Wark,M., Oekermann,T., Ostermann,R., Smarsly,B.M., 2013. Electrodeposition of zinc oxide on transparent conducting metal oxide nanofibers and its performance in dye sensitized solar cells, Electrochim. Acta, 90, 375-381.

[16]. Kang,S.B., Lim,J.W., Na,S.I., Kim,H.K., 2012. Highly near-infrared transparent $\mathrm{GeO}_{2}$ doped $\mathrm{In}_{2} \mathrm{O}_{3}$ electrodes for bulk heterojunction organic solar cells, Sol. Energy Mater. Sol. Cells, 107, 373-380.

[17]. Wolf,N., Stubhan,T., Manara,J., Dyakonov,V., Brabee,C.J. 2014. Stabilization of aluminum doped zinc oxide nanoparticle suspensions and their application in organic solar cells, Thin solid films 564, 213-217.

[18]. Bagheri,N., Aghaei,A., Ghotbi,M.Y., Marzbanrad,E., Vlachopolas,N., Haggman,L., Wang,M., Boschloo,G., $\quad$ Hagfelt,A., Nuckowska,M.S., Kulesza,P.J., 2014. Combination of Asymmetric Supercapacitor Utilizing Activated Carbon and Nickel Oxide with Cobalt Polypyridyl-Based DyeSensitized Solar Cell, Electrochim. Acta, 143, 390-397.

[19]. Chenjing Gao, Qianji Han, Mingxing $\mathrm{Wu}$, Review on transition metal compounds based counter electrode for dye-sensitized solar cells, Journal of Energy Chemistry, 27 (2018) 703-712.

[20]. Jasmin S. Shaikh, Navajsharif S. Shaikh, Sawanta S. Mali, Jyoti V. Patil, Krishna K. Pawar, Pongsakorn Kanjanaboos, Chang Kook Hong, J. H. Kim and Pramod S. Patil, Nanoarchitectures in dye-sensitized solar cells: metal oxides, oxide perovskites and carbon-based materials, Nanoscale, 2018, 10, 4987-5034.

[21]. Facchetti,A., 2011. $\pi$-Conjugated Polymers for Organic Electronics and Photovoltaic Cell Application, Chem. Mater., 23 , 733-758.

[22]. Beaujuge,P.M., $\quad$ Frechet,J.M.J., 2011. Molecular Design and Ordering Effects in $\pi$ Functional Materials for Transistor and Solar Cell Applications, J. Am. Chem. soc., 133, 20009-20029.

[23]. Colsmann,A., Reinhard,M., Kwon,T.H., Kayser,C., Nickel,F., J. Czolk, U. Lemmer, N. Clark, J. Jaisieniak, A.B. Holmes, D. Jones, 2012. Inverted semi-transparent organic solar cells with spray coated, surfactant free polymer top-electrodes, Sol. Energy Mater. Sol. Cells, 98, 118-123.

[24]. Roesch,R., Eberhardt,K.R., Engmann,S., Gobsch,G. Hoppe,H., 2013. Polymer solar cells with enhanced lifetime by improved electrode stability and sealing, Sol. Energy Mater. Sol. Cells, 117, 59-66.

[25]. Zhang,W., Min,C., Zheng,Q., Li,X., Fang,J., 2014. Zwitterionic ammonium and neutral amino molecules as cathode interlayer for inverted polymer solar cells, Organic electronics, 15, 3632-3638.

[26]. Lee,U.J., Lee,S.H., Yoon,J.J., Oh,S.J., Lee,S.H., Lee,J.K., 2013. Surface interpenetration between conducting polymer and PET substrate for mechanically reinforced ITOfree flexible organic solar cells, Sol. Energy Mater. Sol. Cells, 108, 50-56.

[27]. Anju Ramachandran, I. Jinchu, C. O Sreekala, Studies on polymer based counter 
electrodes for DSSC application, 3-5 March 2016, 16487343, IEEE.

[28]. Wenjing Hou, Yaoming Xiao, Gaoyi Han and Jeng-Yu Lin, The Applications of Polymers in Solar Cells: A Review, Polymers (Basel). 2019 Jan; 11(1): 143.

[29]. Ramachandran,R., Mani,V., $\quad$ Chen,S.M., Gnanakumar,G., Govindasamy,M., 2015. Recent Developments in Electrode materials and Methods for Pesticide Analysis - An overview Int. J Electrochem. Sci., 10, 859869.

[30]. Babu, K.J. Zahoor, A. Nahm, K.S. Ramachandran,R., Rajan,M.A.J., Gnanakumar,G., 2014. The influences of shape and structure of $\mathrm{MnO}_{2}$ nanomaterials over the non-enzymatic sensing ability of hydrogen peroxide, J. Nanopart. Res., 16, 2250.

[31]. Ramachandran,R., Mani,V., Chen,S.M., Saraswathi,R., Lou,B.S., 2014. Recent trends in graphene based electrode materials for energy storage devices and sensors applications, Int. J.Electrochem. Sci., 8, 11680-11694.

[32]. Chen, S.M. Ramachandran, R. Mani, V. Saraswathi, R. 2014. Recent advancements in electrode materials for the highperformance electrochemical supercapacitors: a review, Int. J Electrochem. Sci., 9, 4072-4085.

[33]. Wang,W.Y., Ting,P.N., Luo,S.H., Lin,J.Y., 2014. Pulse-reversal electropolymerization of polypyrrole on functionalized carbon nanotubes as composite counter electrodes in dye-sensitized solar cells, Electrochim. Acta, 137, 721-727.

[34]. Zhai,P., Chang,Y.H., Huang,Y.T., Wei,T.C., Su,H., Feng,S.P., 2014. Water-soluble Microwave-exfoliated Graphene Nanosheet/Platinum Nanoparticle Composite and Its Application in DyeSensitized Solar Cells, Electrochim. Acta, 132, 186-192.

[35]. Zhang, Y. Yuan, S. Liu,W., 2014. Inverted organic solar cells employing

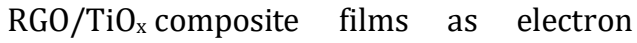
transport layers, Electrochim. Acta, 143, 1822

[36]. Stubhan,T., Kuantz,J., Li,N., Guo,F., Litzov,I., Steidl,M., Richter,M., Matt,G.J., Brabee,C.J., 2012. High fill factor polymer solar cells comprising a transparent, low temperature solution processed doped metal oxide/metal nanowire composite electrode, Sol. Energy Mater. Sol. Cells, 107, 248-251.

[37]. Viyada Harnchana, Sujinda Chaiyachad, Samuk Pimanpang, Chatree Saiyasombat, Pornjuk Srepusharawoot and Vittaya Amornkitbamrung, Hierarchical $\mathrm{Fe}_{3} \mathrm{O}_{4}$ reduced graphene oxide nanocomposite grown on $\mathrm{NaCl}$ crystals for triiodide reduction in dye-sensitized solar cells, Sci Rep. 2019; 9: 1494.

[38]. Leung,D., Fu,X., Wang,C., Ni,M., Leung,M.X., Wang,M., and Fu,X., 2010. Hydrogen Production over Titania-Based Photocatalysts, ChemSusChem, 3(6), 681694.

[39]. Rauf,M., Meetani,M., Hisaindee,S., 2011. An overview on the photocatalytic degradation of azo dyes in the presence of $\mathrm{TiO}_{2}$ doped with selective transition metals, Desalination, 276(13), 13-27.

[40]. Park,H., Park,Y., Kim,W., Choi,W., 2013. Surface modification of $\mathrm{TiO}_{2}$ photocatalyst for environmental applications, J. Photochem. Photobiol., C, 15, 1-20.

[41]. Chen,X., and Mao,S.S., 2007. Titanium Dioxide Nanomaterials: Synthesis, Properties, Modifications, and Applications, Chem. Rev., 107(7), 2891-2959.

[42]. Nah,Y.C., Paramasivam,I., and Schmuki,P., 2010. Doped $\mathrm{TiO}_{2}$ and $\mathrm{TiO}_{2}$ Nanotubes: Synthesis and Applications, ChemPhysChem, 11(13), 2698 -2713.

[43]. Banerjee,A.N., 2011. The design, fabrication, and photocatalytic utility of nanostructured semiconductors: focus on TiO2-based nanostructures. Nanotechnol., Sci. Appl., 4, 35-65.

[44]. Li,G., Richter,C.P., $\quad$ Milot,R.L., Cai,L., Schmuttenmaer,C.A., $\quad$ Crabtree,R.H., Brudvig,G.W., and Batista,V.S., 2009. Synergistic effect between anatase and rutile $\mathrm{TiO}_{2}$ nanoparticles in dye-sensitized solar cells, Dalton Trans., 10078-10085.

[45]. Kim,B.M., Rho,S.G., Kang,C.H., 2011. Effects of $\mathrm{TiO}_{2}$ Structures in Dye-Sensitized Solar Cell, J. Nanosci. Nanotechnol., 11(2), 15151517.

[46]. Scanlon,D.O., Dunnill,C.W., Buckeridge,J., Shevlin,S.A., Logsdail,A.J., Woodley,S.M., Catlow,C.R.A., Powell,M.J., $\quad$ Palgrave,R.G., Parkin,I.P., Watson,G.W., Keal,T.W., Sherwood,P., Walsh,A., and Sokol,A.A., 2013. Band alignment of rutile and anatase $\mathrm{TiO}_{2}$, Nat. Mater., 12(9), 798-801.

[47]. Park,N.G., Van de Lagemaat,J., and Frank,A.J.J., 2000. Comparison of DyeSensitized Rutile- and Anatase-Based $\mathrm{TiO}_{2}$ Solar Cells, Phys. Chem. B, 104(38), 8989-8994.

[48]. Li, J. Yang, X. Yu, X. Xu, L. Kang, W. Yan, W. Gao, H. Liu Z. and Guo, Y. 2009. Rare earth oxide-doped titania nanocomposites with enhanced photocatalytic activity towards the degradation of partially hydrolysis polyacrylamide, Appl. Surf. Sci., 255(6), 3731-3738.

[49]. Kim,H.S., Lee,J.W., Yantara,N., Boix,P.P., Kulkarni,S.A., Mhaisalkar,S., Grätzel,M., Park,N.G., 2013, High Efficiency Solid-State Sensitized Solar Cell-Based on 
Submicrometer Rutile $\mathrm{TiO}_{2}$ Nanorod and $\mathrm{CH}_{3} \mathrm{NH}_{3} \mathrm{PbI}_{3}$ Perovskite Sensitizer, Nano Lett., 3(6), 2412-2417.

[50]. Kamaruzzaman Sopian, Azami Zaharim, Mohd Syafiq Zulfakar, Norasikin Ahmad Ludin, Review on recent performance titanium dioxide for flexible dye sensitized solar cell, 10-12 July 2017, 17138060, IEEE.

[51]. Chen,X., and Mao,S.S., 2007. Titanium Dioxide Nanomaterials: Synthesis, Properties, Modifications, and Applications, Chem. Rev., 107(7), 2891-2959.

[52]. Pardon Nyamukamba, Omobola Okoh, Henry Mungondori, Raymond Taziwa and Simcelile Zinya, 2018. Synthetic Methods for Titanium Dioxide Nanoparticles: A Review, DOI: 10.5772/intechopen.75425

[53]. Nilofar Asim, Shideh Ahmadi, Alghoul, M. A., Hammadi, F. Y., Kasra Saeedfar, Sopian, K. 2014. Research and Development Aspects on Chemical Preparation Techniques of Photoanodes for Dye Sensitized Solar Cells, International Journal of Photoenergy, Article ID 518156, 21

[54]. Gu,F., Huang,W., Wang,S., Cheng,X., Hu,Y., and Lee,P.S., 2014. Open-circuit voltage improvement in tantalum-doped $\mathrm{TiO}_{2}$ nanocrystals, Phys. Chem. Chem. Phys., 16(47), 25679-25683.

[55]. Mor,G.K., Varghese,O.K., Paulose,M., Shankar,K., and Grimes,C.A., 2006. A review on highly ordered vertically oriented $\mathrm{TiO}_{2}$ nanotube arrays: Fabrication, material properties, and solar energy applications, Sol. Energy Mater. Sol. Cells, 90(14), 20112075.

[56]. Yang,M., Kim,D., Jha,H., Lee,K., Paul,J., and Schmuki,P., 2011. Nb doping of $\mathrm{TiO}_{2}$ nanotubes for an enhanced efficiency of dye-sensitized solar cells, Chem. Commun., 47(7), 2032-2034.

[57]. Mohammad

Hossein Nateq and Riccardo Ceccato,2019. Sol-Gel Synthesis of $\mathrm{TiO}_{2}$ Nanocrystalline Particles with Enhanced Surface Area through the Reverse Micelle Approach, Advances in Materials Science and Engineering Article ID 1567824, 14 pages

[58]. Peng,X., and Chen,A., 2004. Aligned $\mathrm{TiO}_{2}$ nanorod arrays synthesized by oxidizing titanium with acetone, J. Mater. Chem., 14, 2542-2548.

[59]. Blesic,M., Saponjic,Z., Nedeljkovic,J., and Uskokovic,D., 2002. $\mathrm{TiO}_{2}$ films prepared by ultrasonic spray pyrolysis of nanosize precursor, Mater. Lett., 54(4), 298-302.

[60]. Wu,X., Jiang,Q.Z., Ma,Z.F., Fu,M., and Shangguan,W.F., 2005. Synthesis of titania nanotubes by microwave irradiation, Solid State Commun., 136(9-10), 513-517.

[61]. Archana,P.S., Gupta,A., Yusoff,M.M., Jose,R., 2014. Tungsten doped titanium dioxide nanowires for high efficiency dye-sensitized solar cells, Phys. Chem. Chem. Phys., 16, 7448-7454.

[62]. Xiaoyan, D. Chengwu, S. Yanru Z. and Ni, W., 2015. Hydrolysis preparation of the compact $\mathrm{TiO}_{2}$ layer using metastable $\mathrm{TiCl}_{4}$ isopropanol/water solution for inorganic-organic hybrid heterojunction perovskite solar cells, J. Semicond., 36(7), 074003.

[63]. Kavan, L. Te'treault, N. Moehl T. and Gra"tzel, M., 2014. Electrochemical Characterization of $\mathrm{TiO}_{2}$ Blocking Layers for Dye-Sensitized Solar Cells, J. Phys. Chem. C, 118(30), 16408-16418.

[64]. Wu,Y., Yang,X., Chen,H., Zhang,K., Qin,C., Liu,J., Peng,W., Islam,A., Bi,E., Ye,F., Yin,M., Zhang,P., Han,L., 2014. Highly compact $\mathrm{TiO}_{2}$ layer for efficient hole-blocking in perovskite solar cells, Appl. Phys. Express, 7(5), 052301.

[65]. Ke,W., Fang,G., Wang,J., Qin,P., Tao,H., Lei,H., Liu,Q., Dai,X., Zhao,X., 2014. Perovskite Solar Cell with an Efficient $\mathrm{TiO}_{2}$ Compact Film, ACS Appl. Mater. Interfaces, 6(18), 1595915965.

[66]. Kavan,L., Regan,B.O., Kay,A., Grätzel,M., 1993. Preparation of $\mathrm{TiO}_{2}$ (anatase) films on electrodes by anodic oxidative hydrolysis of $\mathrm{TiCl}_{3}$, J. Electroanal. Chem., 346(1), 291-307.

[67]. Noh,J.H., Lee,S., Kim,J.Y., Lee,J.K., Han,H.S., Cho,C.M., Cho,I.S., Jung,H.S., Hong,K.S., 2009. Functional Multilayered Transparent Conducting Oxide Thin Films for Photovoltaic Devices, J. Phys. Chem. C, 113(3), 1083-1087.

[68]. Lee,S., Noh,J.H., Han,H.S., Yim,D.K., Kim,D.H., Lee,J.K., Kim,J.Y., Jung,H.S., Hong,K.S., 2009. Nb-Doped $\mathrm{TiO}_{2}$ : A New Compact Layer Material for $\mathrm{TiO}_{2}$ Dye-Sensitized Solar Cells, J. Phys. Chem. C, 113(16), 6878-6882.

[69]. Nah, Y.C. Paramasivam I.and Schmuki, P., 2010. Enhanced photocatalysis on $\mathrm{TiO} 2$ nanotube arrays modified with molecularly imprinted TiO2 thin film, ChemPhysChem, 11(13), 2698-2713.

[70]. Alarco'n,H., Hedlund,M., Johansson,E.M.J., Rensmo,H., Hagfeldt,A., Boschloo,G., 2007. Modification of Nanostructured $\mathrm{TiO}_{2}$ Electrodes by Electrochemical $\mathrm{Al}^{3+}$ Insertion: Effects on Dye-Sensitized Solar Cell Performance, J. Phys. Chem. C, 111(35), 13267-13274.

[71]. Ko,K.H., Lee,Y.C., and Jung,Y.J., 2005. Enhanced efficiency of dye-sensitized TiO2 solar cells (DSSC) by doping of metal ions., J. Colloid Interface Sci., 283(2), 482-487.

[72]. Zhang,J., Han,Z., Li,Q., Yang,X., Yu,Y., Cao,W., 2011. N, S-doped $\mathrm{TiO}_{2}$ anode effect on performance of dye-sensitized solar cells, J. Phys.Chem. Solids, 72(11), 1239-1244. 
[73]. Berglund,S.P., Hoang,S., Minter,R.L., Fullon,R.R., Mullins, C. B. 2013. Investigation of 35 elements as single metal oxides, mixed metal oxides, or dopants for titanium dioxide for dye-sensitized solar cells, J. Phys. Chem. C, 117(48), 25248-25258.

[74]. Hoye,R.L.Z., Musselman,K.P., MacManus Driscoll,J.L., 2013. Research Update: Doping $\mathrm{ZnO}$ and $\mathrm{TiO}_{2}$ for solar cells, APL Mater., 1(6), 060701.

[75]. Duan,Y., Fu,N., Liu,Q., Fang,Y., Zhou,X., Zhang,J., Lin,Y., 2012. Sn-Doped $\mathrm{TiO}_{2}$ Photoanode for Dye-Sensitized Solar Cells, J. Phys. Chem. C, 116(16), 8888-8893.

[76]. Bart Roose, Sandeep Pathak and Ullrich Steiner, 2015. Doping of TiO2 for sensitized solar cells, Chem. Soc. Rev., 2015, 44, 8326-8349

[77]. Meng,S., and Kaxiras,E., 2010. Electron and Hole Dynamics in Dye-Sensitized Solar Cells: Influencing Factors and Systematic Trends, Nano Lett., 10(4), 1238-1247.

[78]. Brinker,C.J., and Scherer,G.W., 1990. Sol-gel science, the physics and chemistry of sol-gel processing, Academic Press, Boston.

[79]. Lamberti,A., Sacco,A., Bianco,S., Manfredi,D., Cappelluti,F., Hernandez,S., Quaglio,M., and Pirri,C.F., 2013. Charge transport improvement employing $\mathrm{TiO}_{2}$ nanotube arrays as front-side illuminated dye-sensitized solar cell photoanodes, Phys. Chem. Chem. Phys., 15, 2596-2602.

[80]. Duan,Y., Fu,N., Zhang,Q., Fang,Y., Zhou,X., and Lin,Y., 2013. Influence of dye of Sn source on the performance -sensitized solar cells based on $\mathrm{Sn}$-doped $\mathrm{TiO}_{2}$ photoanodes: A strategy for choosing an appropriate doping source, Electrochim. Acta, 107, 473480.

[81]. Ahmad,A., Buzby,S., Ni,C., and Shah,S.I., 2008. Effect of $\mathrm{Nb}$ and $\mathrm{Sc}$ Doping on the Phase Transformation of Sol-Gel Processed $\mathrm{TiO}_{2}$ Nanoparticles, J. Nanosci. Nanotechnol., 8(5), 2410-2418.

[82]. Ryan,M., 2009. PGM Highlights: Progress in Ruthenium Complexes for Dye Sensitised Solar Cells. Platinum Metals Review, 53 (4), 216-218.

[83]. Tsai,S., Research on DSSC, Industrial Technology Research Institute, 2008.

[84]. Green,M.A., 1982. Solar Cells, Operating Principles, Technology, and System Applications, Englewood Cliffs, N.J., Prentice-Hall, Inc., 276s., ISBN 0-13822270-3.

[85]. Shelke,R.S., Thombre,S.B., and Patrikar,S.R., Status And Perspectives of Dyes Used in Dye Sensitized Solar Cells, International Journal of Renewable Energy Resources 3 (2013) 54-61.
[86]. Sadig Aghazada ID and Mohammad Khaja Nazeeruddin, Review Ruthenium Complexes as Sensitizers in Dye-Sensitized Solar Cells

[87]. Jihuai $\mathrm{Wu}$, Zhang Lan, Sanchun Hao, Pingjiang Li, Jianming Lin, Miaoliang Huang, Leqing Fang, and Yunfang Huang, 2008. Progress on the electrolytes for dyesensitized solar cells, Pure and Applied Chemistry, 80 (11), 2241-2258, (2008).

[88]. Georg Wolfbauer, Alan M. Bond, John C. Eklund, Douglas R. MacFarlane, 2001. A channel flow cell system specifically designed to test the efficiency of redox shuttles in dye sensitized solar cells, Solar Energy Materials \& Solar Cells, 70, 85-101, (2001).

[89]. Ling,S.C., 2006. The Assembly of Quantum dots and its Application in Dye Sensitized Solar Cell, in Chemical Engineering., National Cheng Kung University: Tainan.

[90]. Badeker,K., 1907. Concerning the electricity conductibility and the thermoelectric energy of several heavy metal bonds, Annalen der Physik, 22, 749.

[91]. Holland, L., 1963. Vacuum Deposition of Thin Films. 1st ed.: Chapman \& Hall Ltd. 555.

[92]. Sahu,D.R., Lin,S.Y., and Huang,J.L., 2008. Investigation of conductive and transparent Al-doped $\mathrm{ZnO} / \mathrm{Ag} / \mathrm{Al}$-doped $\mathrm{ZnO}$ multilayer coatings by electron beam evaporation. Thin Solid Films, 516 (15), 4728-4732.

[93]. Sahu, D. R. Lin, S. Y. and Huang, J. L. 2007. Study on the electrical and optical properties of $\mathrm{Ag} / \mathrm{Al}$-doped $\mathrm{ZnO}$ coatings deposited by electron beam evaporation, Applied Surface Science, 253 (11), 48864890, (2007).

[94]. Subrahmanyam, A. and Barik, U. K. 2005. Synthesis of P-type transparent conducting silver:indium oxide (AIO) thin films by reactive electron beam evaporation technique, Journal of Physics and Chemistry of Solids, 66 (5), 817-822, (2005).

[95]. Christian May, Richard Menner, Johannes Strümpfel, Mike Oertel, Bernd Sprecher, 2003. Deposition of TCO films by reactive magnetron sputtering from metallic $\mathrm{Zn}: \mathrm{Al}$ alloy targets Surface and Coatings Technology, 512-516.

[96]. Vaufrey, D M Ben Khalifa, M.P Besland, C Sandu,J Tardy, 2002. Reactive ion etching of sol-gel-processed $\mathrm{SnO}_{2}$ transparent conducting oxide as a new material for organic light emitting diodes, Synthetic Metals, 127 (1-3), 207-211.

[97]. Dagkaldiran,U., Gordijn,A., Finger,F., Yates,H.M., Evans,P., Sheel,D.W., Remes,Z., Vanecek,M., 2009. Amorphous silicon solar cells made with $\mathrm{SnO}_{2}: \mathrm{F}$ TCO films deposited by atmospheric pressure CVD, Materials Science and Engineering: B, 159-160, 6-9. 
[98]. Sylvie Faÿ, Jérôme Steinhauser, Nuno Oliveira, Evelyne Vallat-Sauvain, Christophe Ballif, 2007. Opto-electronic properties of rough LP-CVD ZnO:B for use as TCO in thinfilm silicon solar cells, Thin Solid Films, 515 (24), 8558-8561.

[99]. Agashe,C., and Mahamuni,S., 2010. Competitive effects of film thickness and growth rate in spray pyrolytically deposited fluorine-doped tin dioxide films, Thin Solid Films, 518 (17), 4868-4873.

[100]. Chen,S.C., 2003. The properities of transparent ductivite oxides ITO deposited on flexible substrate, in Department of Materials Science and Engineering, National Cheng Kung University: Tainan, Taiwan.

[101]. Indium Tin Oxide Technology (ITO), in BizEsp Limited, (2007).

[102]. Novel TCO film-FTO on glass. http://www.materialsnet.com.tw/eng/FTO. html.

[103]. Tsai, F.Y. 2008. The Study of Synthesis of Fluorine-doped Tin Oxide Nanowires and the Electrical Property of a Single Fluorinedoped Tin Oxide Nanowire, in Department of Engineering and System Science, National Ching Hua University: Hsinchu, Taiwan.

[104]. Lin, S. S. 2003. The Investigation for Improving Properties and Application of ZincOxide Films, in Materials Science and Engineering, National Cheng Kung University: Tainan, Taiwan.

[105]. Suchea,M., Christoulakis,S., Katsarakis,N., Kitsopoulos,T., $\quad$ Kiriakidis,G., 2007. Comparative study of zinc oxide and aluminum doped zinc oxide transparent thin films grown by direct current magnetron sputtering, Thin Solid Films, 515 (16), 6562-6566.

[106]. Lee, K.M. Chen, C.Y. Wu, S.J. Chen, S.C. Wu, C.G. 2013. Surface passivation: The effects of CDCA co-adsorbent and dye bath solvent on the durability of dye-sensitized solar cells, Sol. Energy Mater. Sol. Cells, 108, 70.

[107]. Chen,X., Jia,C., Wan,Z., Feng,J., Yao,X., 2014. Effects of different solvent baths on the performances of dye-sensitized solar cells: Experimental and theoretical investigation Organic electronics, 15, 2240.

[108]. Zheng,Y., Li,S., Zheng,D., Yu,J., 2014. Effects of different polar solvents for solvent vapor annealing treatment on the performance of polymer solar cells, Organic electronics, 15, 2647.

[109]. Wang,Y. Zhang,X., Zhang,H., Huang,Q., Yang,F., Meng,X., Wei,C., Zhao,Y., 2014. Room temperature fabrication of highly textured hydrogen and tungsten co-doped ZnO film for solar cell applications, Sol. Energy Mater. Sol. Cells, 121, 49-52.

[110]. Bu,I.Y.Y., 2011. Room temperature synthesis of nanocrystalline silicon by aluminium induced crystallization for solar cell applications, Vacuum 86, 106.

[111]. Sing,P., Ravindra,N.M., 2012. Temperature dependence of solar cell performance-an analysis, Sol. Energy Mater. Sol. Cells, 101, 36-45.

[112]. Xiao,C., Yu,X., Yang,D., Que,D., 2014. Impact of solar irradiance intensity and temperature on the performance of compensated crystalline silicon solar cells, Sol. Energy Mater. Sol. Cells, 128, 427-434.

[113]. Guechi,A., Chegaar,M., Merabet,A., 2011. The Effect of Water Vapor on the Performance of Solar Cells, Physics procedia, 21, 108-114.

[114]. Garcia,A.F., Franco,R.D., Martinez,L., Wette,J., 2014. Study of the Effect of Acid Atmospheres in Solar Reflectors Durability under Accelerated Aging Conditions, Energy procedia, 49, 1682-1691.

[115]. Cantu,M.L., Siddiki,M.K., Rojas,D.M., Amade,R., Pech,N.I.G., 2010. Nb$\mathrm{TiO}_{2}$ /polymer hybrid solar cells with photovoltaic response under inert atmosphere conditions, Sol. Energy Mater. Sol. Cells, 94, 1227-1234.

[116]. Nan,Y.X., Chen,F., Yang,L.G., Jiang,X.X., Zuo,L.J., Zhang,J.L., Yan,Q.X., Shi,M.M., Chen,H.Z., 2011. Photoluminescence enhancement and atmosphere-dependent photovoltaic performance in CdS nanorod arrays/MEH-PPV hybrid, Sol. Energy Mater. Sol. Cells, 95, 3233-3240.

[117]. Gimpel,T., Kontermann,S., Buck,T., Baumann,A.L., Gunther,K.M., Wefringhaus,E., V. Mihailetchi, E. Lemp, D. Rudolph, J. Theobald, W. Schade, Experimental Implementation of a Silicon Wafer Tandem Solar Cell, Energy procedia, 55, 186-189.

[118]. Schneider,A., Traut,N., Hamburger,M., 2014. Analysis and optimization of relevant parameters of blade coating and gravure printing processes for the fabrication of highly efficient organic solar cells, Sol. Energy Mater. Sol.Cells, 126, 149-154.

[119]. Zhang, Y. Wu, R. Shi, W. Guen, Z. Effect of in situ annealing on the performance of spray coated polymer solar cells, Sol. Energy Mater. Sol. Cells, 111, 200-205.

[120]. Xiong,K., Hou,L., Wu,M., Huo,Y., Mo,W., Yuan,Y., Sun,S., Xu,W.W., Wang,E., 2015. From spin coating to doctor blading: A systematic study on the photovoltaic performance of an isoindigo-based polymer, Sol. Energy Mater. Sol. Cells, 132, 252-259.

[121]. Moon,B.H., Sung,Y.M., Han,C.H., 2013. Titanium oxide Films Prepared by Sputtering, Sol Gel and Dip Coating Methods for Photovoltaic Application, Energy procedia 34, 589-596.

[122]. Muhammad,N.M., Sundharam,S., Dang,H.W., Lee,A., Ruy,B.H., Choi,K.H., 2011. CIS layer 
deposition through electrospray process for solar cell fabrication, Current applied phys., 11, S68-S75.

[123]. Peng,S., Wu,Y., Zhu,P., Thavalsi,V., Mhaisalkar,S.G., Ramakrishna,S., 2011. Facile fabrication of polypyrrole/functionalized multiwalled carbon nanotubes composite as counter electrodes in low-cost dye-sensitized solar cells, J. Photo chem. Photobiol., A, 223, 97102.

[124]. Kadhim Al-Attafi, Andrew Nattestad, Shi Xue Dou and Jung Ho Kim A, 2019. Comparative study of TiO2 paste preparation methods using solvothermally synthesised anatase Nanoparticles in Dye-Sensitised Solar Cells, Appl. Sci. 9, 979

[125]. Kang,M.G., Park,H.J., Ahn,S.H., Guo,L.J., 2010. Transparent $\mathrm{Cu}$ nanowire mesh electrode on flexible substrates fabricated by transfer printing and its application in organic solar cells, Sol. Energy Mater. Sol. Cells, 94, 11791184.

[126]. Kopola,P., Aernouts,T., Guillerez,S., Jin,H., Tuomikoski,M., Maaninen,M., 2010. High efficient plastic solar cells fabricated with a high-throughput gravure printing method, J. Hast, Sol. Energy Mater. Sol. Cells, 94, 16731680.

[127]. Voigt,M.M., Mackenzie,R.C.I., King,S.P., Yau,C.P., Atienzar,P., Dane,J.,,Keivanidis,P.E., Zadrazil,I., Bradley,D.D.C., Nelson,J., 2012. Gravure printing inverted organic solar cells: The influence of ink properties on film quality and device performance, Sol. Energy Mater. Sol. Cells, 105, 77-65.

[128]. Susanna,G., Salamandra,L., Brown,T.M., Carlo,A.D., Brunetti,F., Raale,A., 2011. Airbrush spray-coating of polymer bulkheterojunction solar cells, Sol. Energy Mater. Sol. Cells, 95, 1775-1788.

[129]. Kopola,P., Zimmermann,B., Filipovic,A., Schleiermacher,H.F., Greulich,J., Rousu,S., Hast,J., Myllyla,R., Wurfel,V., 2012. Aerosol jet printed grid for ITO-free inverted organic solar cells, Sol. Energy Mater. Sol. Cells, 107, 252-258.

[130]. Burfendt,B., Hannappel,T., Storck,W., Willig,F., 1996. Measurement of Temperature-Independent Femtosecond Interfacial Electron Transfer from an Anchored Molecular Electron Donor to a Semiconductor as Acceptor, J. Phys. Chem., 100, 16463.

[131]. Hannappel,T., Burfendt,B., Storck,W., Willig,F., 1997. Measurement of Ultrafast Photoinduced Electron Transfer from Chemically Anchored Ru-Dye Molecules into Empty Electronic States in a Colloidal Anatase $\mathrm{TiO}_{2}$ Film, J. Phys. Chem., 101B, 6799.
[132]. Durrant, J. R. Tachibana, Y. Mercer, I. Moser, JE Gratzel; M. 1999. Int. J. Res. Phys. Chem., 212, 93.

[133]. Opara Krasovec,U., Berginc,M., Hocevar,M., Topic,M., 2009. Unique $\mathrm{TiO}_{2}$ paste for high efficiency dye-sensitized solar cells, Solar Energy Materials \& Solar Cells, 93, 379-381.

[134]. Veerapandian,S., Amudha,S., Austin Suthanthiraraj,S., Abdul Rahman,M., and Sultan Nasar,A., 2015. Enhanced performance of a nanocrystalline dye-sensitized solar cell based on polyurethane dendrimers, RSC Adv.,

[135]. Ahmed A.Al-Ghamdi, Gupta,R.K., Kahol,P.K., Wageh,S., Al-Turki,Y.A., Shirbeeny,W.E., Yakuphanoglu,F., 2014. Improved solar efficiency by introducing graphene oxide in purple cabbage dye sensitized TiO2 based solar cell, Solid State Communications, 183, 56-59.

[136]. Prabu,K.M., Anbarasan,P.M., Ranjitha,S., 2014. Natural Dye-Sensitized Solar Cells (NDSSCs) From Opuntia Prickly Pear Dye Using ZnO Doped TiO 2 Nanoparticles by Sol- Gel Method, Int. Journal of Engineering Research and Applications, 4(7), 140-149.

[137]. Sanad,M.M.S., Shalan,A.E., Rashad,M.M., Mahmoud,M.H.H., 2015. Plasmonic enhancement of low cost mesoporous $\mathrm{Fe}_{2} \mathrm{O}_{3}-\mathrm{TiO}_{2}$ loaded with palladium, platinum or silver for dye sensitized solar cells (DSSCs), Applied Surface Science, 359, 315322.

[138]. Su Pei Lim, Alagarsamy Pandikumar, Nay Ming Huang, Hong Ngee Lim, Guochen Gu and Ting Li Mad, 2014. Promotional effect of silver nanoparticles on the performance of N-doped TiO2 photoanode-based dyesensitized solar cells, RSC Adv., 4, 4823646244.

[139]. Guangchao Wang, Zhixia Cai, Fengrong Li, Songting Tan, Shuhong Xie, Jiangyu Li, 2014. $2 \% \mathrm{ZnO}$ increases the conversion efficiency of $\mathrm{TiO}_{2}$ based dye sensitized solar cells by $12 \%$, Journal of Alloys and Compounds, 583, 414-418.

[140]. Prabu, K. M., Suguna, K., Anbarasan P. M., Selvankumar T., Aroulmoji V. 2014. Sensitizers Performance of Dye-Sensitized Solar Cells Fabricated with Indian Fruits and Leaves.Int. J. Adv. Sci. Eng. 1(2)24-32.

[141]. Bakhshayesh,A.M., Bakhshayesh,N., 2015. Enhanced performance of dye-sensitized solar cells aided by $\mathrm{Sr}, \mathrm{Cr}$ co-doped $\mathrm{TiO}_{2}$ xerogel films made of uniform spheres, Journal of Colloid and Interface Science 460, 18-28.

[142]. Ranjitha,S., Aroulmoji,V., Lavanya Dhevi,R., Rajarajan,G., Gnanendra,S., 2018. Prominence of Using Betalain and Cubebin as Natural Dye Sensitizers for the Design of Eco-Friendly DSSC's, Int. J. Adv. Sci. Eng. 4(4) 726-736. 
[143]. Cham Kim, Ki-Soo Kim, Ho Young Kim and Yoon Soo Han, 2008. Modification of a $\mathrm{TiO}_{2}$ photoanode by using $\mathrm{Cr}$-doped $\mathrm{TiO}_{2}$ with an influence on the photovoltaic efficiency of a dye-sensitized solar cell, J. Mater. Chem., 18, 5809-5814.

[144]. Jinho Chae, Dong Young Kim, Sujung Kim, Misook Kang, 2010. Photovoltaic efficiency on dye-sensitized solar cells (DSSC) assembled using Ga-incorporated $\mathrm{TiO}_{2}$ materials, Journal of Industrial and Engineering Chemistry, 16, 906-911.

[145]. Qian Hou, Yanzhen Zheng, Jian-Feng Chen, Weilie Zhou,c Jie Denga and Xia Tao,J. 2011. Visible-light-response iodine-doped titanium dioxidenanocrystals for dye-sensitized solar cells, Mater. Chem., 21, 3877-3883.

[146]. Hafez, H., Saif,M., and Abdel-Mottaleb, M.S.A. 2011. Down-converting lanthanide doped $\mathrm{TiO}_{2}$ photoelectrodes for efficiency enhancement of dye-sensitized solar cells. J. Power Sources 196(13), 5792-5796.

[147]. Gayatri Sahu, Kai Wang, Scott W. Gordon, Weilie Zhou and Matthew A. Tarr, 2012. Core-shell $\mathrm{Au}-\mathrm{TiO}_{2}$ nanoarchitectures formed by pulsed laser deposition for enhanced efficiency in dye sensitized solar cells, RSC Advances, 2, 3791-3800.

[148]. Dae-Kue Hwang, Byunghong Leeb and DaeHwan Kima, 2013. Efficiency enhancement in solid dye-sensitized solar cell by threedimensional photonic crystal, RSC Adv., 3, 3017-3023.

[149]. Kenji Kakiage, Toru Tokutome, Shinji Iwamoto, Toru Kyomen and Minoru Hanay, 2013. Fabrication of a dye-sensitized solar cell containing a $\mathrm{Mg}$-doped $\mathrm{TiO}_{2}$ electrode and ${\mathrm{a} \mathrm{Br}_{3}}^{-} / \mathrm{Br}^{-}$redox mediator with a high open-circuit photovoltage of $1.21 \mathrm{~V}$, Chem. Commun., 2013, 49, 179-180.

[150]. Sang Gyun Kim,Myung Jong Ju, In Taek Choi, Won Seok Choi, Hyun- Jung Choi, Jong-Beom Baek and Hwan Kyu Kim, 2013. Nb-doped $\mathrm{TiO}_{2}$ nanoparticles for organic dye-sensitized solar cell, RSC Adv., 3, 16380-16386.

[151]. Geetha,M., Suguna,K., Anbarasan,P.M., 2012. Photoanode Modification in DSSC Using Chromium Doped $\mathrm{TiO} 2$ nanoparticles by sol-gel method, Arch. Phy. Res., 3 (4), 303308.

[152]. Ya Gao, Yaqing Feng, Bao Zhang, Fei Zhang, Xiao Peng, Lin Liu and Shuxian Meng, 2014. Double-N doping: a new discovery about Ndoped $\mathrm{TiO}_{2}$ applied in dye-sensitized solar cells, RSC Adv., 4, 16992-16998.

[153]. Geetha,M., Suguna,K., Anbarasan,P.M., and Aroulmoji,V., 2014. Preparation and Characterisation of Tailored $\mathrm{TiO}_{2}$ nanoparticles Photoanode for Dye Sensitized Solar Cells, International Journal of Advanced Science and Engineering, 1(1), $1-5$.
[154]. Yeji Lee, Jinho Chae, Misook Kang, 2010. Comparison of the photovoltaic efficiency on DSSC for nanometer sized $\mathrm{TiO}_{2}$ using a conventional sol-gel and solvothermal methods, Journal of Industrial and Engineering Chemistry, 16, 609-614.

[155]. Tanyi,A.R., $\quad$ Ekanayake,P., $\quad$ Young,D.J., Hobley,J., Vijila,C., Tan,A.L., Gorelik,S., Subramanian,G.S., $\quad$ Ming,L.C., 2015. Evaluation of surface energy state distribution and bulk defect concentration in DSSC photoanodes based on Sn, Fe, and $\mathrm{Cu}$ doped $\mathrm{TiO}_{2}$, Applied Surface Science, 351(1), 950-961.

[156]. Veerapandian,S., Amudha,S., Austin Suthanthiraraj,S., Abdul Rahman,M., Sultan Nasar,A., 2015. Enhanced performance of a nanocrystalline dye-sensitized solar cell based on polyurethane dendrimers, RSC Adv., 5, 31404-31409.

[157]. Jiang, Y. F., Chen, Y. Y., Zhang, B., Fenga, Y. Q. 2016. N, La Co-Doped $\mathrm{TiO}_{2}$ for Use in LowTemperature-Based Dye-Sensitized Solar Cells, Journal of the Electrochemical Society, 163 (10) F1133-F1138

[158]. Qiuping Liu, Yang Zhou , Yandong duan , Min Wang , Xianhui Zhao , Yuan Lin,2013. Enhanced conversion efficiency of dyesensitized titanium dioxide solar cells by Cadoping, Journal of Alloys and Compounds 548,161-165

[159]. Shaheer Akhtar M., Ahmad Umar., Swati Sood., InSung Jung .,Hegazy H. H., Algarni H. 2019. Rapid Growth of $\mathrm{TiO}_{2}$ Nanoflowers via Low-Temperature Solution Process: Photovoltaic and Sensing Applications, Materials 2 12, 566

[160]. Burschka J, Pellet N, Moon SJ, HumphryBaker R, Gao P, Nazeeruddin MK, Grätzel M. 2013. Sequential deposition as a route to high-performance perovskite-sensitized solar cells. Nature. 2013 Jul 18;499(7458):316-9

[161]. Nasser A.M. Barakat ,M. Shaheer Akhtar , Ayman Yousef , Mohamed El-Newehy , Hak Yong Kim, 2012. Pd-Co-doped carbon nanofibers with photoactivity as effective counter electrodes for DSSCs, Chemical Engineering Journal, 211-212, 9-15.

[162]. Qian Hou, Yanzhen Zheng, Jian-Feng Chen, Weilie Zhou, Jie Denga and Xia Tao, 2011. Visible-light-response iodine-doped titanium dioxidenanocrystals for dye-sensitized solar cells,J.Mater. Chem., 21, 3877.

[163]. Won Ho Jung, Noh-Seok Kwaka, Taek Sung Hwanga,, Kwang Bok Yi, 2012. Preparation of highly porous $\mathrm{TiO}_{2}$ nanofibers for dyesensitized solar cells (DSSCs) by electrospinning, Applied Surface Science, 261, 343352.

[164]. Soon Hyung Kang, Hyun Sik Kim, Jae-Yup Kim, Yung-Eun Sung, 2010. Enhanced 
photocurrent of nitrogen-doped $\mathrm{TiO}_{2}$ film for dye-sensitized solar cells, Materials Chemistry and Physics, 124, 422-426.

[165]. Sang Gyun Kim, Myung Jong Ju, In Taek Choi, Won Seok Choi, Hyun- Jung Choi, Jong-Beom Baek and Hwan Kyu Kim, 2013. $\mathrm{Nb}$-doped $\mathrm{TiO}_{2}$ nanoparticles for organic dyesensitized solar cells, RSC Advances, 3, 16380.

[166]. Qiuping Liu, Yang Zhou, Yandong Duan, Min Wang, Yuan Lin, 2013. Improved photovoltaic performance of dye-sensitized solar cells (DSSCs) by $\mathrm{Zn}+\mathrm{Mg}$ co-doped $\mathrm{TiO}_{2}$ electrode, Electrochimica Acta, 95, 4853

[167]. Yeji Lee, Jinho Chae, Misook Kang,2010. Comparison of the photovoltaic efficiency on DSSC for nanometer sized $\mathrm{TiO}_{2}$ using a conventional sol-gel and solvothermal methods, Journal of Industrial and Engineering Chemistry 16, 609-614

[168]. Feitao Li, Yuzong Gu, 2012. Improvement of performance of dye-sensitized solar cells by doping $\mathrm{Er}_{2} \mathrm{O}_{3}$ into $\mathrm{TiO}_{2}$ electrodes, Materials Science in Semiconductor Processing, 15, 11-14.

[169]. Su Pei Lim, Alagarsamy Pandikumar, Hong Ngee Lim, Ramasamy Ramaraj \& Nay Ming Huang, 2015. Boosting Photovoltaic Performance of Dye-Sensitized Solar Cells Using Silver Nanoparticle-Decorated N,S-CoDoped- $\mathrm{TiO}_{2}$ Photoanode, Scientific Reports, 5, 11922.

[170]. Qiuping Liu , Yang Zhou , Yandong duan, Min Wangc, Xianhui Zhao, Yuan Lin, 2013. Enhanced conversion efficiency of dyesensitized titanium dioxide solar cells by $\mathrm{Ca}-$ doping, Journal of Alloys and Compounds, 548, 161-165.

[171]. Moradzaman,M., Mohammadi,M.R., Nourizadeh,H., 2015. Efficient dyesensitized solar cells based on CNTs and Zrdoped $\mathrm{TiO}_{2}$ nanoparticles, Materials Science in Semiconductor, Processing, 40, 383-390.

[172]. Moaaed Motlak, M. Shaheer Akhtar, Nasser A.M. Barakat, A.M. Hamza, O-Bong Yang, Hak Yong Kim, 2014. High-Efficiency Electrode Based on Nitrogen-Doped $\mathrm{TiO}_{2}$ Nanofibers for Dye-Sensitized Solar Cells, Electrochimica Acta, 115, 493- 498.

[173]. Jun-Yong Park, Kyu-Han Lee, Beom-Soo Kim, Chan-Soo Kim, Sung-Eun Lee, Kikuo Okuyama, Hee-Dong Jang and Tae-Oh Kim, 2014. Enhancement of dye-sensitized solar cells using $\mathrm{Zr} / \mathrm{N}$-doped $\mathrm{TiO}_{2}$ composites as photoelectrodes, RSC Adv., 4, 9946.

[174]. Jung Tae Park, Won Seok Chi, Harim Jeon and Jong Hak Kim, 2014. Improved electron transfer and plasmonic effect in dye-sensitized solar cells with bi-functional Nb-doped $\mathrm{TiO}_{2} /$ Ag ternary nanostructures, Nanoscale, 6, 2718.
[175]. Riccardo Bendoni, Nicola Sangiorgi, Alex Sangiorgi ,Alessandra Sanson, 2015. Role of water in $\mathrm{TiO}_{2}$ screen-printing inks for dyesensitized solar cells, Solar Energy, 122, 497-507.

[176]. Sanad,M.M.S., Ahmed.E. Shalan., Rashad,M.M., $\quad$ Mahmou,M.H.H., 2015. Plasmonic enhancement of low cost mesoporous $\mathrm{Fe}_{2} \mathrm{O}_{3}-\mathrm{TiO}_{2}$ loaded with palladium, platinum or silver for dye sensitized solar cells (DSSCs), Applied Surface Science, 359, 315-32.

[177]. Alagesan Subramanian, Hong-Wen Wang, 2012. Effects of boron doping in $\mathrm{TiO}_{2}$ nanotubes and the performance of dyesensitized solar cells, Applied Surface Science, 258, 6479- 6484.

[178]. Weiqi Wang, Yangqiao Liu, Jing Sun, Lian Gao, 2016. Nitrogen and yttrium co-doped mesoporous titania photoanodes applied in DSSCs, Journal of Alloys and Compounds, 659, 15-22.

[179]. Xiang,P., Ma,W., Xiao,T., Jiang,L., Tan,X., Shu,T., 2016. Ta-doped hierarchical TiO2 spheres for dye-sensitized solar cells, Journal of Alloys and Compounds, 656, 4550.

[180]. Shuming Yang, Shupei Guo, Dongli Xu , Hongbin Xue , Huizhi Kou , Jichao Wang, Guanghui Zhu, 2013. Improved efficiency of dye-sensitized solar cells applied with Fdoped $\mathrm{TiO}_{2}$ electrodes, Journal of Fluorine Chemistry, 150, 78-84.

[181]. Geetha,M., Suguna,K., Anbarasan,P.M., and Aroulmoji,V., 2014. Preparation and Characterisation of Tailored $\mathrm{TiO} 2$ nanoparticles Photoanode for Dye Sensitized Solar Cells Int. J. Adv. Sci. Eng. 1(1) 1-5.

[182]. Kenji Kakiage, Yohei Aoyama, Toru Yano, Keiji Oya, Jun-ichi Fujisawa and Minoru Hanaya, 2015. Highly-efficient dye-sensitized solar cells with collaborative sensitization by silyl-anchor and carboxy-anchor dyes, Chemical Communication, 51, 15894-15897.

[183]. Mozhgan Hosseinnezhad, 2019. Enhanced Performance of Dye-Sensitized Solar Cells Using Perovskite/DSSCs Tandem Design, Journal of Electronic Materials, 48(9), 5403-5408.

[184]. Arunkumar,A., Deepana,S., Shanavas, RobertoAcevedo, Anbarasan,P.M., 2019. Computational Investigation on Series of Metal-Free Sensitizers in Tetrahydroquinoline with Different $\pi$ Spacer Group for DSSCs, ChemistrySelect 4 (14): 4097 - 4104.

[185]. Arunkumar,A Anbarasan,P.M., 2019. Optoelectronic Properties of a Simple MetalFree Organic Sensitizer with Different Spacer Groups: Quantum Chemical 


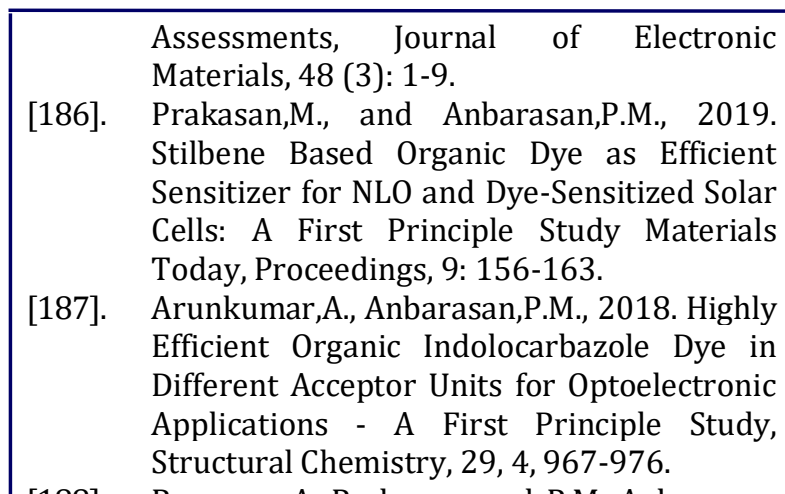

[188]. Ragavan, A. Prakasam and P.M. Anbarasan, Electronic Structure, Nonlinear Optical Properties and Spectroscopic Studies of 4Methyl-3-Nitropyridine-1-Carbonitrile: Using Density Functional Theory, Int. J. Adv. Sci. Eng. 4( 2), 554-565 (2017)

[189]. Sakthi,D., Prakasam,M., Prakasam,A., Sivakumar,S., Anbarasan,P.M., 2017. A Complete DFT, TD-DFT and Non-Linear Optical Property Study on 6-Amino-2Methylpyridine-3-Carbonitrile,

Computational Chemistry, 5, 129-144.

[190]. Padmanathan,S., Ragavan,I., Prakasam,A., and Anbarasan,P.M., 2017. DFT and TD-DFT calculations of 2-aminopyrimidine-5carbonitrile Dye Sensitizer for Solar Cells, Int. J. Adv. Sci. Eng. 3(3) 384-390.

[191]. Sakthi,D., Prakasam,M., Prakasam,A., Sivakumar,S., and Anbarasan,P.M., 2016. Theoretical Investigations of 1,5Diaminoanthraquinone Organic Dye Sensitizer for Dye Sensitizer Solar Cell" Chemical Science Transactions, 5(4), 11071113.

[192]. Prakasam,M., and Anbarasan,P.M., 2016. Second Order Hyperpolarizability of Triphenylamine Based Organic Sensitizers: A First Principle Theoretical Study" RSC Advances, 6, 75242 - 75250.

[193]. Sakthi,D., Prakasam,M., Prakasam,A., Sivakumar,S., and Anbarasan,P.M., 2016. Geometrical, Electronic Structure, Nonlinear Optical and Spectroscopic Investigations of 2-Amino-6-Nitrobenzothiazole as Sensitizer for DSSC, Int. J. Adv. Sci. Eng. 2(4), 168-176.

[194]. Prakasam,M., Arunkumar,A., Priyadharsan,A., Nicksonsebastin,D., and Anbarasan,P.M., 2015. Anthracene Based Organic Dye Sensitizer for Dye Sensitizer Solar Cell: Quantum chemical calculations, Int. J. Adv. Sci. Eng. 2(2), 93-97.

[195]. Mohr,T., Aroulmoji,V., Samson Ravindran,R., Müller,R., Ranjitha,S., Rajarajan,G., and Anbarasan,P.M., 2015. DFT And TD-DFT Study on Geometries, Electronic Structures and Electronic Absorption of Some Metal Free Dye Sensitizers for Dye Sensitized Solar Cells, Spectrochimica Acta PartA:Molecular and Biomolecular Spectroscopy, 135,1066-1073.
[196]. Senthilkumar,P., Nithya,C., Anbarasan,P.M., 2014. Quantum Chemical Investigations on the Effect of Dodecyloxy Chromophore in 4-Amino Stilbene Sensitizer for DSSCs, Spectrochimica Acta Part A: Molecular and Biomolecular Spectroscopy, 22, 15-21.

[197]. Senthilkumar,P., Nithya,C., Anbarasan,P.M., 2013. 2,3'- Diamino- 4,4'Stilbenedicarboxylic acid Sensitizer for Dye Sensitized Solar Cells: Quantum Chemical Investigations" Journal of Molecular Modeling, 19, 4561-4573.

[198]. Anbarasan,P.M., Vasudevan,K., Senthil Kumar,P., Prakasam,A., Geetha,M., and Lalithambigai,K., 2012. Structural and Spectral Properties of 4Phenoxyphthalonitrile Dye Sensitizer for Solar Cell Applications, Bulletin of Materials Science, 35(2,) 265-275.

[199]. Senthilkumar,P., and Anbarasan,P.M., 2011. Molecular Modeling of 4Methylphthalonitrile for Dye Sensitized Solar Cells using Quantum Chemical Calculations, Journal of Molecular Modeling, 17(1), 49.

[200]. Anbarasan,P.M., Senthilkumar,P.M., Vasudevan,K., Govindan,R., and Aroulmoji,V., 2011. Geometries, Electronic Structures and Vibrational Spectral Studies of 4-Aminophthalonitrile using Quantum Chemical Calculations for Dye Sensitized Solar Cells" Indian J. Phys., 85(10), $1477-$ 1494.

[201]. Anbarasan,P.M., Senthil Kumar,P., Vasudevan,K., Moorthy Babu,S., and Aroulmoji,V., 2011. DFT and TD-DFT Calculations of Some Metal Free Phthalonitrile Derivatives for Enhancement of the Dye Sensitized Solar Cells, Acta Physica Polonica (A), 119, 3, 279-288.

[202]. Anbarasan,P.M., Senthil kumar,P., Vasudevan,K., Govindan,R., Prakasam,A., and Geetha,M., 2011. Geometrical, Electronic Structure, NLO and Spectroscopic Investigations of 4(Phenylthio)Phthalonitrile Dye Sensitizer for Solar Cells using Quantum Chemical Calculations - European Journal of Chemistry, 2(2), 206-213.

[203]. Geetha,M., Senthil Kumar,P., Vasudevan,K., Prakasam,P., Meenakshi,G., Anbarasan,P.M., 2010. Study of Geometrical, Electronic Structure, Spectral and NLO Properties of 3,4-Pyridinedicarbonitrile Dye Sensitizer for Solar Cells Using Quantum Chemical Calculations, Journal of Saudi Chemical Society, 14, 399-407.

[204]. Senthil kumar,P., Vasudevan,K., Prakasam,A., Geetha,M., and Anbarasan,P.M., 2010. Quantum Chemistry Calculations of 3Phenoxyphthalonitrile Dye Sensitizer for 
Solar Cells, Journal of Spectrochimica Acta Part A,77(1), 45-50.

[205]. Subramanian,M.K., Anbarasan,P.M., and Manimegalai,S., 2010. Molecular Structure, Vibrational Spectroscopic Studies and NBO Analysis of 7-Amino- 4Trifluoromethylcoumarin, Pramana, 74(5), 845-850.
[206]. Ranjitha, S., Aroulmoji, V., Mohr, T., Anbarasan, PM., Rajarajan G, 2014. Structural and Spectral Properties of 1, 2dihydroxy-9, 10-anthraquinone Dye Sensitizer for Solar Cell Applications, Acta Physica Polonica a 126 (3), 833-839, 441. 